Trakya Eğitim Dergisi

Cilt 9, Sayı 4

2019 Ek Sayı

Aralık 2019, 847-868

Geliş Tarihi: 28.02.2019

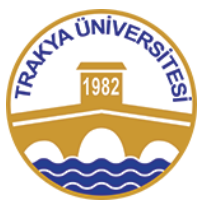

ISSN: 2630-6301
Trakya Journal of Education

Volume 9, Issue 4

2019 Additional Issue

December 2019, 847-868

Yayına Kabul Tarihi: 06.12.2019

DOI:10.24315/tred.533604

Araştırma Makalesi

\title{
Sınıf Öğretmenliği Eğitiminin Niteliğinin Artırılmasına Yönelik Öğretmen Adayları ve Öğretim Elemanı Görüşleri ${ }^{1}$
}

\section{Prospective Teachers' and Instructors' Views on Increasing the Quality of Primary School Teacher Education}

\section{Mehmet ÖNER', Ruhan KARADA $\breve{G}$ YILMAZ}

\begin{abstract}
Öz: Bu araştırmanın amacı sınıf öğretmenliği eğitiminin niteliğinin artırılmasına yönelik öğretmen adayları ve öğretim elemanlarının görüşlerini belirlemektir. Araştırmada nitel araştırma yöntemi benimsenmiş; veriler sınıf öğretmenliği programına kayıtlı 20 son sınıf öğrencisi ve sınıf ögretmenliği programında derse giren 10 öğretim elemanıyla yapılan görüşmeler yoluyla toplanmıştır. Öğretmen adaylarının ve öğretim elemanlarının görüşlerini ortaya çıkarmak amacıyla nitel araştırma veri toplama tekniklerinden yarıyapılandırılmış görüşmeler yapılmış, betimsel analiz tekniğinden yararlanılarak toplanan verilerin analizi gerçekleştirilmiştir. Araştırma sonucunda elde edilen bulgular son yıllarda sınıf öğretmenliği programına yerleşen öğrencilerin profilinde akademik nitelik bağlamında düşüş yaşandığını, sınıf öğretmenliği programına yerleşen öğrencilerin yarısından fazlasının bölümü severek ve isteyerek tercih etmediğini, programda sınıf öğretmenliğine katkısı olmayan derslerin fazla olduğunu ve verilen derslerin dağılımının ve içeriğinin düzensiz olduğunu ortaya çıarmıștır. Ayrıca alanında uzman öğretim elemanı yetersizliği yaşandığı, sınıf mevcutlarının kalabalık olduğu, öğretmen adaylarının atama kaygısı yaşadığından derslerden verim alamadığı araştırmanın önemli diğer sonuçları arasındadır. Sınıf öğretmenliği eğitiminin niteliğinin artırılmasına dönük öğretim elemanları ve öğretmen adaylarının önerilerine bakıldığında sınıf öğretmenliği programına öğrenci alımında kriterlerin gözden geçirilmesi ve sınıf öğretmenliği programında ders geçme not sisteminde değişiklik yapılması gerektiği sıkça vurgulanan görüşler arasındadır.
\end{abstract}

Anahtar sözcükler: Sinıf ögretmenliği, öğretmen eğitimi, ögretmen ĕgitiminde nitelik, öğretmen adayları, ögretim elemanları

\begin{abstract}
The aim of this study is to determine the views of prospective teachers and instructors about increasing the quality of primary school teacher education. The qualitative research method has been adopted in this research. The data were collected through interviews with 20 senior students and 10 instructors in the primary school teacher education program. In order to collect the data, semistructured interview technique, which is one of the qualitative research methods, was used to reveal the opinions of prospective teachers and instructors. Descriptive analysis technique was used in data analysis. It was revealed that more than half of the preservice teachers did not prefer the primary teacher education program willingly. Also preservice teachers think that there are more courses in the program that do not contribute to primary school teaching and the distribution and content of the courses is scattered. Considering the suggestions of instructors and prospective teachers towards increasing the quality of primary school teacher education is frequently emphasized that the criteria for students' admission to the primary school teaching program should be reviewed. In addition, participants think that a change of course system should be made in the primary school teaching program.
\end{abstract}

Keywords: Primary school teacher education, teacher education, qualification of teacher education, prospective teachers, teaching staff

\section{EXTENDED ABSTRACT}

\section{Introduction}

Teacher education is a multidimensional and comprehensive process that includes teacher education programs, policies, and teaching processes designed to equip prospective teachers with knowledge, skills and attitudes needed to effectively fulfill their duties in the classroom, school and a wider community. Increasing the quality of teacher education is a topic discussed in many cultures. Since the primary teaching is the basis of the whole educational life and success in life, the process of raising the primary school teacher is in a higher position than the other teacher education programs.

The policies of the world's most successful education systems focus on increasing the professional development of the teacher. Therefore, it has become an important issue to increase the quality of education,

\footnotetext{
${ }^{1} \mathrm{Bu}$ makale birinci yazarın yüksek lisans araştırma projesinden üretilmiştir.

2 Öğretmen, MEB, Siverek Şirinkuyu İlkokulu, Şanlıurfa, Türkiye, mehmettoner02@gmail.com, ORCID:0000-0003-3568-7538

${ }^{3}$ Doç.Dr. Adıyaman Üniversitesi, Eğitim Fakültesi, Temel Eğitim Bölümü, Adıyaman - Türkiye, rkaradag@adiyaman.edu.tr, ORCID:0000-0003-3254-8890
} 
education standards and education policies. Also nowadays, in order to increase the qualifications of teachers, academic studies are carried out in details in many countries.

In this study, it is thought that determining the views of the instructors and prospective teachers will contribute to the projects to be developed in the teacher education program and the strategies to be developed in order to increase the quality of primary school teacher education programs. In this context, the following sub-problems were answered: education?

- What are the views of prospective teachers to increase the quality of primary school teacher

-What are the views of the instructors to increase the quality of primary school teacher education?

\section{Method}

This research is designed in the qualitative research model. The purpose of this research is to determine the views and suggestions of the senior students and the instructors in the primary school teacher education program about increasing the quality of primary school teacher education. Criterion sampling was used in this research. The participants of this study consist of 20 prospective teachers and 10 instructors in the primary school education program. In this research data were collected by semi-structured interviews. Descriptive analysis technique was used to analyze the data.

\section{Result and Discussions}

At the end of the study it was found out that more than half of the prospective teachers did not prefer the primary school teacher education program willingly. The number of prospective teachers who did not prefer the program willingly is high due to the fact that there is a low employment concerns and to find jobs easily according to other departments. One of the important findings of the study is that the prospective teachers believe that the practical application of the lessons contribute to them more. Prospective teachers want to remove the unnecessary courses in the program and to focus on more learner centered and practical courses such as effective communication, diction, educational psychology. Also they think that credit hours of teaching practice should be increased. It is revealed that the majority of them believe that the teaching staffs entering the courses do not have sufficient knowledge and skills. In addition prospective teachers think that teacher education is insufficient due to the crowded class size. Another point of this research is to determine the opinion of the instructors in the primary school teacher education program about the increasing the quality of the program. Instructors think that quota increases in primary school teacher education department in recent years caused a decrease in the quality of students academically. In this respect, instructors emphasized that student numbers in primary school teacher education department should be reduced. According to the instructors, the education given in the faculty is not sufficient to educate the ideal primary school teacher. Since there are an insufficient number of qualified faculty members in the primary school teacher education program, the prospective teachers are not be able to get benefits from the instructors entering the courses effectively. As a result of the study, it was stated that the selection of prospective teacher candidates and the teacher education process should be rearranged academically and technically in the faculties of education. Based on the results of the research, the following suggestions can be made to increase the quality of primary school teacher education:

- The primary school teacher education program should be reviewed and developed in order to be balanced in terms of theory and practice.

- The proportion of teaching vocational courses should be higher in the primary school teacher education program.

- Students who have positive attitudes and interest in teaching profession should be encouraged to enroll primary school teacher education program. Also pre-selection applications (interviews, aptitude test etc.) should be carried out to ensure successful students enter the program.

- The courses in the primary school teacher education program should be provided by experts.

\section{GİRIŞ}

Günümüzde pek çok ülkede okulların rolü ve işleyişi değişmekte, buna bağlı olarak öğretmen rollerinde önemli değişiklikler gündeme gelmektedir. Değişen bilim ve teknoloji dünyasına uyum sağlayabilmek amacıyla öğretmenlerden giderek daha çok kültürlü sınıflarda ders vermeleri beklenmekte, özel öğrenme gereksinimi olan öğrenciler için kapsayıcı öğrenme ortamları yaratmaları, bilgiyi daha etkin kullanmaları, öğretim teknolojilerinden yararlanmaları, kanıta ve değerlendirmeye dayalı öğretim uygulamaları gerçekleştirmeleri istenmektedir. $\mathrm{Bu}$ doğrultuda eğitim fakülteleri öğretmen eğitimi programlarını yaşam boyu öğrenme, teknolojideki gelişim ve uygulamalardan yararlanarak uygun alternatif 
planlama stratejileri üretebilme, eylem araştırması kullanarak süreçte karşılaşılan sorunlarla başa çıkabilme, ulusal bütünleşme ve uluslararası anlayış için doğru bilgi, tutum ve duyguları geliştirebilme gibi hedefler doğrultusunda geliştirmekte ve güncellemektedir. Bu süreçte öğretmen de bilginin hızla arttığı ve çabucak eskidiği bilgi çağında tek bilgi kaynağı olarak görülmek yerine, öğrenciye bilgiye erişme yollarını öğreten ve araştıran öğretmen profiline dönüşmüştür. Bu niteliklere sahip öğretmenlerin yetiştirilmesinde ise eğitim fakültelerinin ve fakültelerde uygulanan öğretmen eğitimi programlarının rolü oldukça büyüktür.

Öğretmen eğitimi, öğretmen adaylarını sınıfta, okulda ve daha geniş bir toplulukta görevlerini etkin bir biçimde yerine getirmek için gereksinim duyulan bilgi, beceri, davranış ve tutumlarla donatmak için tasarlanmış programlar, politikalar ve öğretim süreçlerini içeren çok boyutlu ve kapsamlı bir süreçtir. Öğretmen eğitimi o ülkede bireylerin yetişen neslin yaşama hazırlanmasına verdiği değeri yansıttığından, ülkelerin eğitim politikalarında kontrol derecesi değişkenlik gösteren bir süreçtir. Bu nedenle günümüzde, öğretmen eğitiminin niteliğini artırma pek çok kültürde tartışılan bir konudur.

Öğretmen eğitimi, ülkelerin eğitim sisteminin yenilenmesinde ve güçlendirilmesinde hayati bir rol oynamaktadır (Dilshad ve Iqbal, 2010). Dünyanın en başarılı eğitim sistemlerinin politikalarında, öğretmenin mesleki gelişiminin artırılmasına odaklanılmaktadır. Bu nedenle eğitim politikalarında eğitim standartlarının ve kalitesinin yükseltilmesinde, öğretmenin niteliğinin artırılmasına ve öğretim kalitesini sağlamaya yönelik çabalarının artırılması önemli bir konu haline gelmiştir (Jamil, 2014). UNICEF (2000) ve Thaung (2008) tarafından öğrenci, öğretmen, içerik, öğretme-öğrenme süreçleri ve öğrenme ortamları eğitim kalitesi göstergeleri arasında sunulmuştur. Dilshad ve Iqbal (2010) da öğretmen eğitimi programlarının öğretmen eğitiminde kalite göstergeleri arasında yer aldığını belirtmektedir. Öğretmen eğitimi programlarının yanı sıra öğretmen adaylarının seçimi, programa yerleşen öğretmen adaylarının özellikleri, hizmet öncesi eğitimleri, programda yer alan öğretim üyelerinin nitelikleri ve eğitim fakültelerinin eğitim ortamları da öğretmen eğitimini doğrudan ve dolaylı olarak etkileyen değişkenler arasında yer almaktadır (Şimşek, 2005; Tunca ve diğerleri, 2015).

Öğrenen başarısının niteliği öğretmen eğitimi programları ile öğretim süreçlerinin niteliğine ve öğretmen yeterliğine bağlıdır. Öğretmenin mesleki gelişiminin öğrenci başarısı üzerindeki olumlu etkisi ilgili çalışmaların çoğu tarafından da ortaya konulmuştur (Desimone, 2009; Wei, Andree ve DarlingHammond, 2009). Hanushek, Kain ve Rivkin (2004) ve Hattie (2009) öğretmen niteliğinin çocuğun okul başarısına katkıda bulunan ve başarısını etkileyen en önemli faktör olduğunu belirtmektedir. Aynı zamanda Craig, Kraft ve Plessis (1998) öğretmen eğitiminin ve öğretmen eğitimi programlarının niteliğinin öğrencilerin başarısını büyük ölçüde etkilediğini ifade etmektedir. Camelia ve Elisabeta (2013) ile Dilshad (2010) da öğrenci başarısının büyük ölçüde öğretmenlerin hizmet öncesi aldıkları öğretmen eğitimine dayandığını ifade etmektedir. Bir öğretmenin sınıf ve okul bağlamındaki performansının niteliği, hizmet öncesinde aldığı öğretmen eğitimi ile hizmet içinde katıldığ 1 hizmet içi eğitim ve mesleki gelişim etkinliklerine bağlıdır (Menon, 2007). Bu nedenle meslekte tam donanımlı olarak hizmet verebilmeleri için öğretmen adaylarının hizmet öncesinde gerekli nitelik ve yeterlikleri kazanmaları gerekmektedir (Bayındır, 2015). Hizmet öncesi öğretmen yetiştirmede öğretmen adaylarının seçilmesi, yetiştirilmesi, öğretmen yetiştiren yükseköğretim kurumlarının yeterliliği, öğretim programlarının içeriği, yapısı, öğretim üyelerinin niteliği gibi faktörler ön plana çıkmaktadır (Can, 2017). Ancak, yetişmekte olan neslin girmeye hazırlandığ dünya ve bu dünyaya uyum sağlayabilmeleri için gereksinim duydukları beceriler çok hızlı bir şekilde değiştiğinden, günümüzde uygulanan öğretmen eğitimi programları ve yürütülen eğitim politikaları yetersiz kalmaktadır. Nitekim, Çelikten, Şanal ve Yeni (2005) tarafindan ülkemizde hizmet öncesi öğretmen eğitimi sürecinde istenilen başarı ve verim elde edilemediği belirtilmekte, Sarıtaş (2007) ve Oktay (1991) tarafından da hizmet öncesi öğretmen eğitiminin öğretmenlik mesleği açısından önemli sorunlardan biri olduğu vurgulanmaktadır.

Ülkemizde, öğretmen yetiştirme görevi 1981 yılında üniversitelere devredildikten sonraki süreçte çeşitli gerekçelerle öğretmen eğitimi programlarında ve eğitim fakültelerinin akademik yapısında birtakım düzenlemeler ve güncellemeler gerçekleştirilmiştir (Yılmaz ve diğerleri, 2017). Bu süreçten itibaren öğretmenlerin niteliklerinin artırılması amacıyla öğretmen yeterliklerinin tanımlanmasından öğretmen eğitimi modellerinde yenilik arayışlarına ve öğretmenlik mesleğine yönelik toplumsal bakışın değiştirilmesine kadar geniş ve kapsamlı akademik çalışmalar gerçekleştirilmektedir (Koyuncu, 2016). Ancak YÖK tarafindan 1998-1999 eğitim öğretim yılından itibaren öğretmen eğitiminde akreditasyonu sağlayabilmek ve niteliği artırabilmek amacıyla birtakım düzenlemeler yapılmasına rağmen, mevcut durumun amaçlanan düzeye hâlâ gelemediği belirtilmektedir (Y1lmaz ve diğerleri, 2017). Öğretmen eğitimi sürecinde sorunlarla karşılaşıldığ 1 ve eksikliklerin bulunduğu gerçeği pek çok akademisyen ve eğitimci tarafından da vurgulanmaktadır. Öğretmen eğitimi sürecinde üzerinde en fazla tartışmaların yaşandığı alan, 
bireyin tüm eğitim yaşantısının temelini oluşturması bakımından önem taşıyan sınıf öğretmenliği alanıdır. Akyol (2011) sınıf öğretmenliğinin hem alanlar açısından hem de ilişkiler açısından farklı bir konumda olduğunu belirtmekte ve sınıf öğretmenlerinin seçilme ve yetiştirilme süreçlerine azami özen gösterilmesi gerektiğine dikkat çekmektedir. Sınıf öğretmenlerinin niteliğini artırmak için yetiştirme uygulamalarının yeniden gözden geçirilmesi ve düzenlenmesi gerektiği belirtilmektedir. Bu durum aklımıza "Sınıf öğretmeni nasıl yetiştirilir? Sınıf öğretmenliği eğitiminin niteliğinin artırılması için neler yapılabilir?" gibi soruları getirmektedir (Akyol, 2011, 13).

Bireyin tüm eğitim yaşamının ve hayattaki başarısının temeli olması nedeniyle sınıf öğretmeni yetiştirme süreci diğer öğretmenlik alanlarına göre etki gücü daha yüksek olan bir konumdadır. $\mathrm{Bu}$, sınıf ögretmenlerinin öğrencilerin gelecekte gereksinim duyacağı temel bilgi, beceri, tutum ve davranışları kazanmalarının yanı sıra toplumun tutum ve değerlerinin de öğrenenlere aktarılmasını sağlayan en önemli etmen olması nedeniyle anlaşılabilir bir durumdur. Kaya, Polat ve Karamüftüoğlu (2014) eğitimin odak noktasındaki kişilerin öğretmen yetiştirme ile ilgili görüşlerinin belirlenmesinin öğretmen yetiştirme sürecinin niteliğinin artırılmasına katkı sağlayacağını belirtmektedir.

\subsection{Araştırmanın Amacı}

$\mathrm{Bu}$ araştırmada sınıf öğretmenliği eğitiminin niteliğinin artırılması için öğretim elemanları ve öğretmen adaylarının görüşlerinin belirlenmesinin alanda yapılacak projeler ve geliştirilecek stratejilere katkıda bulunacağı düşünülmektedir. Dolayısıyla, bu çalışma sınıf öğretmeni yetiştirme noktasında niteliği artırmaya yönelik sınıf öğretmeni adayları ve öğretim elemanlarının görüşlerini belirlemeyi amaçlamaktadır. Bu bağlamda aşağıdaki alt sorulara yanıt aranmıştır:

- Sınıf öğretmenliği eğitiminin niteliğini artırmaya yönelik öğretmen adaylarının görüşleri nelerdir?

- Sınıf öğretmenliği eğitiminin niteliğini artırmaya yönelik öğretim elemanlarının görüşleri nelerdir?

\section{YÖNTEM}

\section{Araştırmanın Modeli}

$\mathrm{Bu}$ araştırma sınıf öğretmenliği eğitiminin niteliğinin artırılmasına yönelik sınıf eğitimi bölümü 4 . sınıf öğrencilerinin ve sınıf eğitimi programında derslere giren öğretim elemanlarının görüş ve önerilerinin neler olduğunun belirlenmesini amaçladığından, nitel araştırma modellerinden fenomenoloji (olgubilim) deseni kullanılarak gerçekleştirilmiştir. Nitel araştırma, doğal ortamlarda, gerçekçi ve bütüncül bir biçimde algıların ve olayların ortaya konulması amacıyla kullanılan bir araştırma yöntemidir (Yıldırım ve Şimşek, 2000, 19). Fenomenolojik araştırma deseni ise farkında olduğumuz ancak derinlemesine ve ayrıntılı bir anlayışa sahip olmadığımız olgulara odaklanmaktadır (Yıldırım ve Şimşek, 2013).

\section{Katılımcilar}

Araştırmada amaçlı örneklem yönteminden ölçüt örneklem kullanılmıştır. Örneklem seçiminde, görüşme yapılan öğrencilerin sınıf öğretmenliği programının son sınıf öğrencileri olması ve görüşme yapılan öğretim elemanlarının sınıf öğretmenliği programında derslere giriyor olması şeklinde iki temel ölçüt dikkate alınmıştır.

Araştırmada sınıf öğretmenliği programında öğrenim gören son sınıf (4.sınıf) 20 öğrenci ve aynı programda dersleri yürüten 10 öğretim elemanı ile görüşme yapılmıştır. Araştırmaya katılan öğretmen adaylarının yaşlarına bakıldığında en küçüğünün 21, en büyüğünün ise 26 yaşında olduğu belirlenmiştir. Cinsiyet açısından ele alındığında ise öğretmen adaylarının 12'si bayan 8'i de erkektir. Araştırmaya katılan öğretim elemanlarının ise hepsinin bay olduğu görülmektedir. Öğretim elemanlarının mesleki kıdemine bakıldığında en az mesleki deneyime sahip öğretim elemanının 7; en fazla mesleki deneyime sahip olanın ise 25 yıllık deneyiminin olduğu görülmüştür.

\section{Verilerin Toplanması}

Araştırma verilerinin toplanmasında nitel araştırma yöntemlerinden yarı yapılandırılmış görüşme tekniği kullanılmıştır. Bu amaçla araştırmacılar tarafından biri öğretmen adaylarından diğeri ise öğretim elemanlarından veri toplamaya yönelik 2 ayrı görüşme formu hazırlanmıştır. Görüşme formlarının hazırlanmasında öncelikle araştırma ile ilgili yazılar taranarak tez, makale, araştırma, dergi, kitap vb. kaynaklar incelenmiştir. Hazırlanan görüşme formlarının içerik geçerliğini sağlamak amacıyla görüşme formları alandan iki uzman tarafından incelenmiş, alan uzmanlarının sunduğu görüşler doğrultusunda taslak formlara son biçimi verilmiş ve görüşme formları uygulamaya hazır duruma getirilmiştir. Görüşmeye 
katılacak katılımcıların belirlenmesinden sonra, müsait oldukları bir tarih belirlenerek randevu alınmıştır. Belirlenen gün ve saatlerde öğretmen adayı ve öğretim elemanları ile bir araya gelerek görüşmeler sağlanmıştır. Öğretmen adayları ile görüşmeler ikinci araştırmacının kendi ofisinde, öğretim elemanları ile görüşmeler de öğretim elemanlarının ofislerinde gerçekleştirilmiştir. Yapılan görüşmelerde görüşmenin amacı açıklanarak aşamaları anlatılmıştır. Görüşme formları öğretmen adayı ve öğretim elemanlarına okutularak her biri için ayrı ayrı imza altına alınarak sözleşme imzalanmıştır. Görüşmelerin hepsi birinci araştırmacı tarafından yüz yüze gerçekleştirilmiştir. Görüşmeye başlamadan önce görüşmeye katılan katılımcılara görüşme yönergesinin okunması sağlanmıştır. Görüşme soruları her bir katılımcıya aynı sıralama ile sorulmuş, soruların yanıtı konunun dışına çıkıldığında, katılımcıların uygun bir dille tekrar konuya dönmesi sağlanmıştır. Görüşme yapılan mekâna katılımcılar dışında hiç kimse girmemiştir. Görüşmelerde öğretmen adaylarına 14, öğretim elemanlarına ise 18 soru yöneltilmiştir. Görüşmeler yaklaş1k 30-50 dakika sürmüştür. Araştırmada veri kaybını önlemek ve verilerin güvenirliğini sağlamak amacıyla yapılan görüşmelerde ses kayıt cihazı kullanılmıştır.

\section{Verilerin Analizi}

Araştırma verilerinin analizinde betimsel analiz tekniği kullanılmıştır. Betimsel analizde elde edilen veriler daha önceden belirlenen başlıklar (temalar) altında özetlenip yorumlanabileceği gibi (Yıldırım ve Şimşek, 2005), veri toplama aşamalarında (gözlem ya da görüşme) elde edilen ön bilgiler 1şığında da düzenlenebilir (Altunışık ve diğerleri, 2001). Bu araştırmada veri toplama aşamasında elde edilen veriler 1şı̆̆ında temalar oluşturulmuştur. Betimsel analizde verilerin düzenlenerek ve sik s1k doğrudan alıntılar verilerek yorumlanması, neden-sonuç bağlarının sorgulanması ve anlaşılır bir biçimde betimlenerek okuyucuya sunulması amaçlanmaktadır (Yıldırım ve Şimşek, 2005, 224). Araştırmada verilerin betimsel analizi "betimsel analiz için bir çerçeve oluşturma, tematik çerçeveye göre verilerin işlenmesi, bulguların tanımlanması ve yorumlanması olmak üzere dört aşamada gerçekleştirilmiştir.

Yarı yapılandırılmış görüşmeler sırasında ses kayıt cihazına kaydedilen veriler bilgisayar ortamında transkript haline getirilmiştir. Bu aşamada katılımcıların görüşme sorularına verdikleri yanıtların birebir yazılmasına dikkat edilmiştir. Ayrıca ses kayıtları bilgisayar ortamında transkripte dönüştürüldükten sonra bir kez de okunarak kayıtlarda hata olup olmadığı belirlenmiştir. Daha sonra veriler her soru için ayrı ayrı analiz edilmiş ve tematik kodlar oluşturulmuştur.

\section{Araştırmanın Güvenirliği}

Araştırmacılar tarafından birbirinden bağımsız bir biçimde yapılan analizlerden sonra belirlenen tema ve kategoriler karşılaştırılarak "görüş birliği" ile "görüş ayrılığı" olanlar tartışılmış ve araştırmanın güvenirliği Miles ve Huberman'ın (1994) önerdiği Güvenirlik = Görüş Birliği / (Görüss Birliği + Görüş Ayrılı̆̆g) kodlama güvenirlik hesaplamasına dayalı olarak yapılmıştır. Yapılan hesaplamalar sonucu kodlamaların güvenirliği \% 90.2 çıkarak güvenilir olduğu kabul edilmiştir. Bunun yanı sıra, araştırma verilerinin analizi sonrasında oluşturulan temalar, görüşmeye katılan bireylerin çarpıcı görüşlerinden doğrudan alıntılar yansıtılarak desteklenmek suretiyle araştırmanın güvenirliği artırılmaya çalışılmıştır. Alıntılarda katılımcılara araştırmacılar tarafından verilen kod isimler kullanılmıştır. Kodlamalarda katılımcılar ad ve soyadlarının baş harfleri alınarak; öğrenci katılımcıların kodlaması AE, BG, EE, ECS, FÇ, İÖ, MC, MZA, MÇ, MG, NA, AM, RY, SG, SGG, SK, SB, ÜGÇ, ZG, ZF; öğretim elemanları ise AK, AN, AC, BK, EY, GD, RG, SD, SÇ, YD şeklinde gösterilmiştir.

\section{Sayıltılar ve Sinırlılıklar}

Araştırmada, sınıf öğretmeni adaylarının ve öğretim elemanlarının araştırma sırasında kendilerine veri toplama araçlarına samimi ve doğru cevaplar verdikleri varsayılmıştır. Araştırma Adıyaman Üniversitesi Eğitim Fakültesi Sınıf Öğretmenliği programındaki 4. sınıf öğrencileri ve sınıf öğretmenliği bölümünde derse giren ve araştırmaya gönüllü katılım sağlayan öğretim elemanlarının görüşleri ve veri toplama aracı olarak görüşme formlarında yer alan sorular ile sınırlıdır.

\section{BULGULAR}

$\mathrm{Bu}$ bölümde araştırmanın alt amaçları doğrultusunda katılımcılara yöneltilen sorular görüşme formundaki soru sırası dikkate alınarak sunulmuştur. Sınıf öğretmenliği eğitiminin niteliğinin belirlenmesine yönelik görüşler öğretmen adaylarının ve öğretim elemanlarının görüşleri şeklinde iki ana başlık altında yer almaktadır. 


\section{Öğretmen Adaylarının “Sınıf Öğretmenliği Eğitiminin Niteliğini Artırmaya Yönelik Görüşleri”ne İlişkin Bulgular}

Öğretmen adaylarının sınıf öğretmenliği eğitiminin niteliğini artırmaya yönelik görüşleri "bölümü tercih etme durumu, programa ilişkin görüşler, verilen eğitimin niteliğine ilişkin görüşler ve sınıf öğretmenliği eğitiminin niteliğini artırmaya yönelik görüş ve öneriler" olmak üzere dört ana tema altında toplanmıştır.

Sınıf öğretmeni adaylarının sınıf öğretmenliğini tercih etme durumlarına ilişkin görüşleri Tablo 1' de sunulmuştur.

Tablo 1. Öğretmen adaylarının sınıf öğretmenliğini tercih etme durumlarına ilişkin görüşler

Alt tema ve
kategoriler Görüşler

Sınıf öğretmenliğini severek ve isteyerek mi seçtiniz?

- "Hayır, eminim ki arkadaşlarımın çoğu da severek seçmedi... Puan sistemine göre geldik, yani mecburiyetten geldik.”(AE).

Hayır

- "Zorunlu, yani kendi isteğim yönünden gelmedim. Hem ailevi ve hem çevresel faktörler etkili oldu. Bir de geleceği vardı bu mesleğin bizim geldiğimiz zaman, o yüzden seçtim." (MÇ).

- "Daha çok iş imkânlarına, geleceğine baktım. Mesleğin geleceği nasıl, bitirirsem atanır mıyım diye, daha çok o yöne bakarak seçtim.” (í).

- "Kesinlikle severek ve isteyerek seçtim, şöyle de söyleyebilirim üniversite tercih döneminde 30 tercih hakkımız vardl, ben 22-23 tane tercih yaptım. Bunlardan 20 tanesi sınıf ögretmenliği, diğer

Evet ikisi de çocuk gelişimiydi. Kesinlikle üniversite tercihi yapacak birinin ilgi, istek ve yeteneğine göre bir tercih yapmast gerekiyor." (ECS).

- "Fark ettim ki ben seviyorum bu çocukları, iyi de yapacağıma inanıyorum çünkü insanlarla becerilerim iyi ve şu anda gerçekten seviyorum. "(MC).

Tablo 1'de görüldüğü gibi, kendisiyle görüşülen öğretmen adaylarının büyük çoğunluğunun bu bölümü severek ve isteyerek tercih etmediği ortaya çıkmıştır. Katılımcıların büyük çoğunluğu sınıf öğretmenliğinde atama kaygısı ve sıkıntısı olmadığından dolayı sınıf öğretmenliği bölümünü tercih ettiğini görüşmeler sırasında vurgulamışlardır. Öğretmen adaylarının büyük bir bölümü sınıf öğretmenliğinin mesleki imajının düştüğünü, bu nedenle bölümü tercih eden öğretmen adaylarının da niteliğinde ciddi anlamda azalma olduğunu belirtmişlerdir. Öğretmen adaylarının mesleğe yönelik tutumları ve mesleği isteyerek seçme durumları onların meslek hayatında mesleğin önemli olduğunun bilincine ulaşmalarında ve mesleğe olan bağl1lıklarında büyük önem taşımaktadır. Öğretmenlik mesleğindeki başarı öğretmen adaylarının hizmet öncesinde bu mesleğe ilişkin olumlu tutum geliştirmelerine ve mesleği sevmelerine bağlıdır. Mesleği isteyerek tercih etmeyen öğretmen adaylarının öğretmenlik yaşantılarında mesleki kimliklerinin de tam oluşmayacağını ve öğretmenliğin imajını olumlu bir biçimde yansıtacak tutum sergileyemeyeceklerini söylemek olanaklıdır.

Sınıf öğretmenliği mesleğini isteyerek seçmediğini belirten öğretmen adaylarından MG "Bence en büyük sorun ögretmenliğe verilen önemin artık ortadan kalkmış olması. Yani, hakaret olarak algılanmasın ama insan kalitesi sürekli düşüyor, birey kalitesi sürekli düşüyor. Sinıf öğretmenliği artık bir işe yaramıyorsa, parayla, işe alınmayla, paralı işlere bakıldiğı için kimse rağbet etmiyor. Onun için sürekli seviyenin düştüğünü düşünüyorum" biçiminde görüşlerini ifade ederken FÇ de "Gelen ögrenci potansiyeli belli... Üniversiteye sadece 4 yll okumak için gelen çok insan var. Sinıf öğretmenliğini sadece 4 yıllık okumak için değil ya da daha basit ve kolay olduğu için değil, aslında bir eğitim neferi olmak, bir eğitimci olarak neler yapılacağını görmek için okumak gerekir. Bir söz vardır. Bir yılı düşünüyorsanız pirinç ekin bir on yıl sonrasını düşünüyorsanız fidan ekin. Yüz yıl sonrasını düşünüyorsanız insan yetiştirin. Aslında ögretmenliği de bu misyona getirebilirsek bence o zaman gerçekten eğitim fakülteleri işin hakkı vermiş olacak" diyerek sınıf öğretmenliğine gereken önemin verilmesi gerektiğini dile getirmektedir. 6 öğretmen adayı ise ilgi, istek ve yeteneğine bu bölümün daha uygun olduğunu ve bu bölümü isteyerek tercih ettiğini belirtmiştir. $\mathrm{Bu}$ öğretmen adaylarına göre sınıf öğretmenliği programına yerleşecek adayların sınıf öğretmenliğini isteyerek ve severek tercih etmeleri, bu mesleğe maddi kazançtan ziyade birincil amaç olarak bakılması gerekmektedir.

Sınıf öğretmeni adaylarının programa ilişkin genel görüşlerini belirlemek amacıyla öğretmen adaylarına "Tekrar sınıf öğretmenliği bölümünü okusaydınız en çok hangi konu ve alanlar üzerinde durulmasını isterdiniz? Programda yer alan derslere ilişkin görüşleriniz nelerdir? ve "Lisans programında 
verilen genel kültür, alan bilgisi ve öğretmenlik meslek bilgisi derslerinin dağılımı hakkındaki görüşleriniz nelerdir?" soruları yöneltilmiştir. Öğretmen adaylarının programa ilişkin genel görüşleri "Programda istenen yenilik ve düzenlemeler", programda yer alan dersler ve ders dağılımlarına ilişkin görüşler" alt temaları altında sunulmuştur. Öğretmen adaylarının programın geneline ilişkin görüşleri Tablo 2' de sunulmuştur.

Tablo 2. Sınıf öğretmenliği programına ilişkin öğretmen adaylarının görüşleri

Tekrar sınıf öğretmenliği bölümünü okusaydınız en çok hangi konu ve alan üzerinde durulmasını isterdiniz?

Eğitim dersleri, gelişim ve öğrenme psikolojisi, öğrenme, öğretim yöntem ve teknikleri

Derslerle ilgili daha fazla kitap okuma ve kaynak materyal kullanımı özendirilmeliydi.

Verilen eğitim ile mesleki hayatta karşılaşılacak konular arasinda bağlantılar olmalıydı.

Sinıf yönetimi

“Sınıf Öğretmenliği Programında Yer Alan Derslere İlişkin Görüşleriniz Nelerdir?

Uygulamaya dayalı dersler yetersiz./ Uygulamalı ders saatleri artırılmalı.

Eğitime katk1 sağlamayacak çok fazla ders var. /

Alan bilgisi derslerinin sayısı az.

Ders saatlerinin dağılımı orantisız.
- "En çok eğitim dersleri. Pedagojik formasyon derslerinin üzerinde çok çok durulmasını isterdim. Yani özellikle gelişim psikolojisi, ögrenme psikolojisi, ögretim yöntem teknikleri kısmında ögrencilerin çok donanımlı olması gerekiyor"(ASM).

- "Özellikle gelişim psikolojisi çok çok önemli. Çocuk somut işlemler döneminde neyi alglllyor, neyi algllayamiyor. Benim konuştuklarımda neyi düşünüp şematize edebiliyor, edemiyor. Bunu çok iyi bir şekilde bilmek gerekiyor” (FÇ)

- "En çok öğretim derslerinin üzerinde durulmasını isterdim, çünkü teorik bilgiyi bilsek de ilköğretimde önemli olan onu aktarabilmektir öğrenciye, uygulamalı olarak derslerin üzerinde durulmasını isterdim" (ÜGÇ).

- "Sürekli teori ve sıkıcı bilgiler ögrrencinin zihninde kalmıyor, biraz önce mesela çıktığımız özel eğitim dersinde hocamızın habire otistik demesi çok siktı, otistiği kendisi anlatsa, filmle yansitsa, daha çok aklımızda kalır, kesinlikle pratiğe yönelik olmall." (MC).

- "Ben burada başka bir şey öğreniyorum, okulda başka bir şeyi öğreteceğim, bence arada bir bağın olması gerekiyor. "(ZG)

- “Örneğin bize Freud'dan falan bahsediyorlar ama Freud'un bir tane kitabını alın okuyun diyen bir ögretmen görmedim. Yani o dersin temellerini oluşturan kişilerin kaynaklarına ulaşmamız gerektiğini düşünüyorum." $(M G)$

- "Mesela kaynaklardan da muzdaribiz. Kendimizi geliștirecek yeterli ve etkili kaynakları bulamıyoruz. Hocalar da mesela bize bu konuda yön göstermiyor. Bunlardan da şikayetçiyiz.” (ZF)

- "Öğrenci psikolojisiyle sinavlara bile hep fotokopilerle hazırlandık, ders kitaplarının dışında bizim alanımıza yönelik, kendimizi geliştirmeye yönelik kitaplar arttırllabilirdi.” (SGG)

- "En çok sıkıntı çektiğimiz şey stajda sınıf yönetimi, ögrencilerle ilişkiler... En çok bunun üzerinde durulması gerektiğini düşünüyorum” (MG).

- "Teorik derslerin bir işe yaradığını düşünmüyorum. Teorik derslerin her yerde, öğretmen okula gelmeden, öğretmen yüzü görmeden de alınabileceğini düşünüyorum. Daha çok pratik, uygulama derslerinin okulda özellikle staj derslerinin daha geniş tutulması gerektiğini düşünüyorum." (MG)

- "Tabii ki uygulama dersleri. Onlara daha ağırlık verilmesi gerekiyor. Çünkü gerçek sınıf ortamına gittiğimiz zaman stajlarda da görüyoruz, en büyük eksiklik sinıfa hakimiyet, ögrencilerin her biriyle göz teması, iletişim kurabilmek. Bilgi birikimimiz var, hepsini anlatabiliyoruz. Ama önemli olan bildiğini bütün sınıfa anlatabilmek, gösterebilmek. O yüzden uygulamaya ağırlı verilmeli. " $(Z F)$

- "Öğrenciye daha fazla katkı sağlayacak derslerin olması lazım, çok gereksiz dersler var."

- "Yetersiz. Alanımızla ilgili derslerin ders sayısının arttırılması gerektiğini düşünüyorum.” (SGG)

- "Bilgiye dayal derslere çok fazla ağırlık verilmemesi gerekiyor. Gelişim psikolojisi ve ögretim yöntem ve tekniklerine ăğrlık verilirse daha güzel bir şekilde yola devam edilir" (FÇ) 
Meslek bilgisi ve eğitim bilimleri derslerine ağırlık verilmeli
- "Eğitim dersleri bence ĕgitim fakültesinin bel kemiği gibi. Az önce de ögretmenlerimizde eleştirdiğim nokta ögrenileni karşıya yansitma, anlatabilme. Biz ne kadar bilgi sahibi olursak olalım ögrencilerimize aktaramadıktan sonra bir önemi yok. Buradan yola çıkarak bana göre ĕgitim dersleri çok daha fazla olmalı. Programı daha geniş kapsamalı ve daha etkin bir şekilde işlenmeli." (FÇ)

- "Matematik, sosyal bilgiler ve ilk okuma ve yazma ögretimi derslerine ăgırlık verilmesi gerekiyor” (AM).

Tablo 2'de görüldüğg̈ gibi öğretmen adaylarının öğretmen eğitimi sürecinde eksikliğini en çok hissettikleri konu ve alanlar arasında eğitim bilimleri dersleri, gelişim ve öğrenme psikolojisi, öğretim yöntem ve teknikleridir. Öğretmen adayları derslerin daha kalıcı olabilmesi ve yaşamla bağlantılı olması gerektiğini vurgulayarak uygulamalı bir biçimde derslerin işlenmesi gerektiğini belirtmişlerdir. Bunun yanı sıra öğretmenlik uygulaması dersine gereken önemin verilmediğini belirten öğretmen adayları da bu konuda eğitim fakültesinde eksiklik olduğunu vurgulamışlardır. Kendisiyle görüşülen öğretmen adaylarının yarısına yakınının "Tekrar sınıf öğretmenliği bölümünü okusaydınız en çok hangi konu üzerinde durulmasını isterdiniz?" soruna öğretmenlik uygulaması dersi üzerinde daha çok durulması gerektiği şeklindeki görüşleri dikkat çekmektedir. Araştırmaya katılan öğretmen adaylarının bir kısmı lisans programında verilen genel kültür, alan bilgisi ve öğretmenlik meslek bilgisi derslerinin ders saati dağılımını orantısız bulurken, birkaç öğretmen adayı ise uygulama derslerine ağırlık verilmesi gerektiği görüşünü benimsemektedir. Araştırma bulgularına göre katılımcılar sahaya inip oradaki öğretmen ve uygulamalardan deneyim ve tecrübe edinmenin kendilerine daha fazla katkı sağlayacağı inancındadırlar. Araştırma sonucunda sınıf öğretmenliği programında yer alan derslerin ve ders içeriklerinin tekrar gözden geçirilmesi sonucuna varıldığından, bu ders ve ders içeriklerinin yeniden düzenlemesinin daha verimli ve etkili bir sınıf öğretmenliği programı oluşturulmasına katkı sağlayacağı öğretmen adayları tarafından vurgulanmıştır. Aynı zamanda öğretmen adaylarına katkı sağlamayacak derslerin olduğu belirtilerek bu derslerin yerine daha işlevsel ve işevuruk derslerin konulması gerektiği ifade edilmiştir.

Araştırmanın alt amaçlarından biri de öğretmen adaylarının öğretim hizmetinin niteliğine ilişkin görüşlerinin belirlenmesidir. Sınıf öğretmeni adaylarının "Verilen eğitimin bugün için size katkısının ne derece yeterli olduğunu düşünüyorsunuz?" sorusuna ilişkin görüşleri “öğretim hizmetinin niteliği” ve “öğretim elemanlarının niteliği” alt temaları altında Tablo 3' te verilmiştir.

Tablo 3. Verilen eğitimin bugün için size katkısının ne derece yeterli olduğunu düşünüyorsunuz?" sorusuna ilişkin görüşler

Verilen Eğitimin Bugün İçin Size Katkısının Ne Derece Yeterli Olduğunu Düşünüyorsunuz?

- "Açık konuşmak gerekirse verilen eğitimin çok da üst düzey bir ĕgitim olduğunu düşünmüyorum. Çoğu arkadaşımda da ben bunu gözlemledim. 1.sınıfta nasıl geldiyse 4.sınıfta da öyle gidiyorlar. Lisede öğrendiklerimin çok da üstünde bir şey ögrenmedim” (FÇ)

Yetersiz

- " Herhangi bir katkıda bulunduğunu düşünüyorum. Öğrencinin o etkinliğe hazırlanmasi için yeterince zamanının da olduğunu düşünmüyorum. Doğru dürüst yönergelerin de verildiğini düşünmüyorum. Yapılan işin de kalitesiz işler olduğunu söylemek gerekiyor" (MG)

- "Bence bu kişiye bağlı bir şey yani senin kendini ne kadar geliştirdiğine bă̆ll. Bir anlatım olduğu zaman örnĕgin bir ögretim dersinde atıorum; ilk okuma yazma

Kısmen ögretiminde bir anlatımım var, ben bu anlatıma bir gece öncesinde de yeterli hazırlanabilirim, bir hafta öncesinden de iyi bir hazırlık yaparak kendimi geliştirerek bu konuda daha çok bilgi edinerek de hazırlanabilirim. Bu aslında kişiye bağlı bir şey...” (ECS).

-“Kendi üniversitemiz açısından bakarsam mesela Türkiye’de ün salmış bir sürü

Yeterli üniversiteye oranla verilen eğitim açısından anlatıyorum gerçekten de şaşırtıcı ama iyi bir üniversite” (MC)

Derse Giren Öğretim Elemanlarının Akademik Bilgi, Beceri ve Donanımları Hakkındaki Düşünceleriniz Nelerdir?

- "Hocalarımız akademik anlamda ülkemizde çok başarılı isimler, saygı duyuyorum ama öğrenciye bir şeyler aktaramadıktan sonra uluslararası profesör olsan bence çok

Akademik anlamda da bir önemi yok"(FÇ)

- "Örneğin slaytla yansıtıyorlar hocalarımız ve çarşaf çarşaf yazılarını okuyorlar. Bu kesinlikle doğru bir şey değil... Her gelen hocamı böyle slayt ve projeksiyon kullanıyor ve bu sıkıcı oluyor." (MC) 
İlgisiz,

özensiz ve - "Derslere gereken önemin verilmemesinin yanı stra anlatımlar da yüzeysel”.

isteksiz.

Akademik

bilgi

yönünden

yeterli

- "Tabi ki hepsi kendi alanında gelişmiş, kendini geliştirmiş insanlar, onların bilgisi olduğunu düşünüyorum ama derse gelen hocaların sınıfa aktarma konusunda bir yetersizliği var." (SG)

Tablo 3’te görüldügü gibi katılımc1ların büyük çoğunluğunda eğitim fakültesinde verilen öğretmen eğitiminin niteliğine ilişkin "yetersiz" olduğu görüşü hâkimken, çok az kısmı verilen eğitimin yeterli olduğunu düşünmektedir. Kendisiyle görüşme yapılan öğretmen adaylarının yarısına yakını öğretim elemanlarını donanım olarak yetersiz ve ilgisiz görürken bir kısmı ise öğretim elemanlarını yeterli bilgi ve donanıma sahip olmakla birlikte bilgiyi aktarma konusunda yetersiz görmektedir.

Sınıf öğretmeni adaylarının "Sınıf öğretmenliği eğitiminin niteliğinin artırılabilmesi için görüş ve önerileriniz nelerdir?” sorusuna ilişkin görüş ve önerileri Tablo 4'te sunulmuştur.

Tablo 4. Sınıf öğretmeni adaylarının sınıf öğretmenliği eğitiminin niteliğinin artırılmasına yönelik görüş ve önerileri

Sınıf öğretmenliği eğitiminin niteliğinin artırılmasına yönelik görüş ve önerileriniz nelerdir?"

Uygulamaya daha

- "Öğretmenlik uygulamaları dersinin 1 sene olmaması gerekiyor. Bunun fazla önem arttırılmasını istiyorum." (ECS)/ - "Daha çok sahaya inilmesi gerektiğini, daha çok verilmeli.

Gereksiz dersler programdan çıkarılmalı/ Dersler arasında denge sağlanmali/ Ders saatlerinin dağılımı düzenlenmeli okullarla iş birliği içerisinde uygulama derslerinin arttırllması gerektiğini düşünüyorum." (MG)

- “Öğrenciyi geliştiren yani sadece sınıf öğretmeni olarak değil de bireyi geliştiren bir program olduğunu düşünmüyorum sınıf öğretmenliği programının. Genel kültür anlamında, diğer farklı konular anlamında bir gelişmenin sağlandığını düşünmüyorum. Daha farklı alanlarda eklemelerin yapılması gerektiğini düşünüyorum” (MG)

- "Öncelikle öğrencilerin bu bölüme nasıl geldikleri, kaç puanla geldikleri, üniversitedeki kontenjan sayıs belirlenmeli. Puanların daha da yükseltilmesi, kontenjanların daha daraltılması bu seviyeyi artıracaktır. "(SG)

Programa giriş - “Öğrenci sayısın azaltılmasıyla bölüme yerleşen ögrencilerin puanı doğal olarak standartları gözden geçirilmeli yükselmiş olacak ve nitelik artışı sağlanmış olacak. Ve öğrenci ile bire bir ilgilenilecek. Ögrencilerin atanma sıkıntısı o kadar yüksek düzeyde olmayacak. ”(FÇ) - "Bu bölüme ögrretmenlik yapabilecek potansiyele sahip ögrencilerin önceden belirlenmesi gerekiyor. Bu alanda yeterliliği var mi, buna bakıp bu bölüme yerleştirilmesi gerekiyor" (MÇ)

Öğretmenlik "Sürekli olarak seviyenin düştüğ̈̈nü düşünüyorum. Yani herkes hukuk fakültesine mesleğine ilişkin tutum ve motivasyon artırılmalı gitmek istiyor, tıp okumak istiyor. Çünkü bunların maddi olarak geliri daha fazla olduğu zaman düşünsel kalitesi yüksek insanlar onlara yöneliyor, sinıf ögretmenliği de öyle hiç bir işe yaramayan, sanki stradan insanların barındı̆̆ bir alan gibi durmaya başladı."(MG)

- "Değişmesi gereken en önemli şey sınıf öğretmeni adayının bu kadar alınmamast. Az önce nitelikten bahsettik. Bunun temelinde yatan en büyük sorun alınan ögrenci sayısı diyebilirim. İkinci öğretim kapanmasına ră̆men mevcut aynı. Lisedeki gibi

Programa alınan sadece sınıf ögretmenliği bölümünde A,B ve C şubeleri var. Ne kadar da komik değil öğrenci sayısı azaltılmalı mi. Dersler işlenemiyor. Ve çoğu kez hocalar gruplara bölerek dönem sonuna dersi yetiştirmeye çalışlyor. İşlenen derslerin hiçbir manası olmuyor. Öğrenci sayısını değiştirmedikçe müfredatta ne kadar değişiklik yapılırsa yapılsın. Siz istediğiniz kadar konu ekleyin, onlart yetiştiremeyeceksiniz. Müfredat içi doldurulmaktan ziyade belki sadeleştirilebilir ama işlenen konu hakk verilerek işlenmeli." (FÇ)

- "Hoca ögrenciyi dinlemiyor bile, size önem vermiyor. Laboratuvarda işlenen dersler sadece işlensin diye işleniyor. Önemli olan bu derslerin içlerini doldurmak. Topluma hizmet diye bir dersimiz var mesela. Öğretmen de ögrenci de başından salmak için işliyor dersi." (FÇ) 
programda

görevlendirilmeli

$\begin{array}{ll}\text { Öğretim } & \text { Bence daha da kendilerini geliştirmeleri gerekiyor. Özellikle öğrencilerle ilişkilerde } \\ \text { üyeleriyle } & \text { daha profesyonelce davranmaları gerekiyor. Yani bir akademisyen, üniversitede } \\ \text { öğrenciler } & \text { ögretim üyesi... Hala kendi hisleriyle ögrencilere davranan ögretmenlerin olduğunu } \\ \text { arasındaki } & \text { görüyoruz. Yani birine yaptığı davranışı başkasına farklılaştırarak yapıyor. Burada } \\ \text { etkileşim } & \text { öğrenciden daha profesyonelce, hislerini katmadan bütün ögrencilere eşit bir şekilde } \\ \text { artırılmalı } & \text { ifade olană̆ının tanınması gerektiğini düşünüyorum.” (MG) }\end{array}$

Tablo 4’te görüldüğü gibi öğretmen adaylarının büyük bir kısmı sınıf öğretmenliği eğitiminin niteliğinin artırılması için uygulamaya daha fazla önem verilmesi ve gereksiz derslerin programdan çıkarılması gerektiği görüşünde birleşmektedir. Bunun yanı sıra öğretmen adaylarının sınıf öğretmenliği programına giriş standartlarının gözden geçirilmesi, programa alınan öğrenci sayısının azaltılması, öğretmenlik mesleğine ilișkin tutum ve motivasyonun artırılması, alan uzmanı öğretim elemanlarının programda görevlendirilmesi ve öğretim elemanlarıyla öğrenciler arasındaki etkileşimin artırılması yönünde görüss ve önerilerinin olduğu dikkat çekmektedir.

\section{Öğretim Elemanlarının "Sınıf Öğretmenliği Eğitiminin Niteliğini Artırmaya Yönelik Görüşleri”ne İlişkin Bulgular}

Öğretim elemanlarının sınıf öğretmenliği eğitiminin niteliğini artırmaya yönelik görüşleri "ideal sınıf öğretmeni/öğretmen adayında bulunması gereken nitelikler, hizmet öncesi verilen eğitimin ideal sınıf öğretmenini şekillendirmedeki etkisi, sınıf öğretmeni adayı profillerine ilişkin görüşler, sınıf öğretmenliği bölümündeki öğretim elemanlarının niteliklerine ilişkin görüşler, sınıf öğretmenliği programına ilişkin görüşler ve sınıf öğretmenliğinde ilk müdahale edilmesi gereken alanlar/konulara ilişkin görüş ve öneriler" alt temaları altında toplanmıştır.

Öğretim elemanlarının “Sizce ideal sınıf öğretmeni ve sınıf öğretmeni adayı nasıl olmalı?” sorusuna ilişkin görüşleri Tablo 5' te verilmiştir.

Tablo 5. İdeal sınıf öğretmeni/öğretmen adayında bulunması gereken niteliklere ilişkin öğretim elemanı görüşleri

\section{İletişim becerisi \\ Pedagojik bilgi ve beceri}
Mesleğe ilişkin olumlu tutum Disiplinler arası ilişki
kurma becerisi

\section{Bilgiyi kullanabilme}

Kendini geliştirme
- "Mezun ettiğimiz öğrencilerimizin bir kısmı öğretmenlik yapamayacak durumda. Hem psikolojik olarak hem de dil yeteneği olarak kişisel gelişim boyutunda yani sınıfiyla konuşmayan, hiç kimseyle iletişimi olmayan ögrencilerimiz var ve bu öğrencilerimiz sınıf öğretmeni olacaklar. Yani dört yıl sınıftaki arkadaşına selam vermemiş bir insan nasıl sını ögretmeni olabilir?." (BK)

- "Tek bir tipoloji tarif edemeyiz ama bazı özelliklerin sinıf ögretmenlerinde avantaj sağlayabileceğini söyleyebiliriz. Bunlar nedir peki? Çocuk sevmesi çok önemli. Çocukları küçük yetişkinler olarak değil de kendi düşünme biçimleri olan varlıklar olduğunu bilmek gerekiyor (AC)

“-Her sene sinıf ögretmenliğine gelen ögrencilere birinci sınıfta kimlerin isteyerek geldiğini soruyorum. Kırk öğrenciden üç ya da dört tanesi isteyerek sinıf ögretmenliğini isteyerek seçiyor. Diğerleri atama ihtimali, öğretmen olmanın kolay olması, iş bulma gibi ihtimaller dâhilinde sınıf ögretmenliğini seçiyor.” (BK)

- "Sinıf ögretmeni kendine has bir disiplini olmayan, birden fazla disiplinde yetiştirilmesi tabi bunu bilim adamı değil de ögretmen hüviyetiyle yetiştirilmesi gereken bir şahis. Ansiklopedik bir insan, bütün disiplinleri iç içe yoğurabilen, Türkçe dersinde matematikten, hayat bilgisi dersinde fenden bahsedebilen bir insan. Ilkokul öğretmeni bu. Yani fen dersinde sadece fen hocası değil o, her şeyin hocasi. Çocuğun o beklentileri var. Bu süpermen... Bu her şeyi bilen adam... O her şeyi bilen adamı her derste uyanı tutmak yani matematik dersinde de Türkçeden bahsetmek. " (AÜ)

- "Günümüzde öğretmen adaylarını bilgi birikimiyle yüklemek kesinlikle doğru bir yaklaşım olmayacak. Ne yapmamız lazım? Bu bilgiyi kullanabiliyor mu? Buna dikkat edeceğiz...." (AK)

- "Ideal sını öğretmeni o derslere girebilecek donanıma sahip olması lazım yani eğitim sürecinde bir kere o kapıdan girdiğinde halletmesi lazım yenileme güncelleme şartlar ayrı bir konu, lisan ögrenip de kendini kırsal bir köyde ya da birleştirilmiş bir sınıfta kendini ögretmen olarak yetiştirmesi lazım” (EY) 


\author{
Program bilgisi ve \\ program geliştirme \\ becerisi
}

Ruh sağlı̆̆ı

\section{Bilişsel, duyuşsal ve psikomotor alan bilgisi}

\section{Proje üretebilme ve yaratıcı düşünme becerisi Bütün bilim dallarına ilişkin bilgi sahibi olmalı Öğrencinin gizil yeteneklerini keşfetme becerisi}

- "Bilgi çok değişiyor. Dünyada yılda bir buçuk iki milyon kitap basıllyor. Internet ortamını hiç saymıyorum bile. Dolayısıyla bu çăgda sınıf ögretmeni olmak çok yaratıcı çok kabiliyetli ve kendi programını, kendi müfredatını yapabilen yeterlilikte olmak demek" (BK)

- “...Geçmiş psikolojik profilini incelemekte yarar var. Yani sağlıklı bir psikolojiye sahip olmast gerekiyor.” (AK)

- “ İdeal bir sınıf ögretmenin sahip olması gereken özellikleri bir eğitimci olarak bilişsel duyusal psikomotor olmak üzere üç alanda incelememiz lazım... Akademik boyutu dediğimiz bu bilişsel alanla ilgili belli düzeyde bilgi birikimine sahip olmakla birlikte o bilgiyi kullanabilme yeteneğine sahip olduğunu göstermesi gerekir giriş sinavinda... Duyusal boyut en az bilişsel ve psikomotor alan kadar önemli. duyusal boyut çok önemli. Öğretmenlik mesleği bir sevgi mesleği olduğunu unutmamak lazım. Hele hele sınıf ögretmeni sanıyorum ki üniversite hocasından da kat kat daha önemli. Çünkü temel teşkil ediyor. Ĕ̆ger temel sağlam değilse gerisinin sağlam olduğuna inanmiyorum. (AK)

- "Projeler üretebilen bir yapıda olması gerekiyor. Ve ögrencilerde veya çocuklarda farklı bakış açılarını geliştirebilecek yaratıcı düşünce beyinlerine sahip olan insanlar olmasi gerekiyor" (AC).

"Sınıf ögretmenlerinin bütün bilim dalları hakkında bilgilerinin, fikirlerinin olması gerekiyor.” (EY)

Sinıf ögretmeninin görevi Einstein yetiştirmek değil, Einsteinleri keşfetmektir. (BK)

Kendisiyle görüşülen öğretim elemanlarının "ideal sınıf öğretmeni/sınıf öğretmeni adaylarının" sabırlı, çocukları seven ve onları tanıyan, sosyal yönden iletişimi kuvvetli, programa ilişkin derin bilgi sahibi ve program geliştirme yeterliğine sahip, disiplinler arası ilişki kurabilme gibi becerilere sahip olması gerektiği görüşlerinin ön plana çıktığı görülmektedir.

Öğretim elemanlarının "Verdiğiniz eğitimin ideal olan sınıf öğretmenini şekillendirmede ne kadar etkili olduğunu düşünüyorsunuz? sorusuna ilişkin görüşleri Tablo 6' da sunulmuştur.

Tablo 6. Hizmet öncesi verilen eğitimin ideal sınıf öğretmenini şekillendirmedeki etkisine ilişkin öğretim elemanı görüşleri

Etkili değil. Kendi alanında uzman olan akademisyenler derslere girmeli.

\section{Uzmanlığını tamamlamış nitelikli öğretim üyesi sayısının az oluşu verilen eğitimin kalitesini düşürdüğünden yetişen sınıf öğretmenleri de niteliksiz olmaktadır.}

\section{Öğretmenlik uygulaması dersi ciddiye alınmadığından yetersiz.}

- "Bu alanda çok fazla yetişmiş öğretim elemanımız olmadiğından dolayı hangi hoca hangi alanda eğitim görmüşse öğretmen adayına da o alanda eğitim vermeye çalışıyor. Aslında ĕgitim fakültelerine verilecek olan ĕgitim sisteminde belli oranda eğitimcilerin veyahut o alanda uzmanlaşmış akademisyenin o dersi vermesi gerekir. Fakat ülkemizde eğitimci olan biri bütün derslere aspirin gibi yetişmeye çalışıyorlar. Bu eğitimde büyük bir sıkıntı" (GD)

- "Sınıf ögretmenliği yapacak kişinin bu alanda doktora yapmış olması lazım, dolayısıyla hem teoriğini hem de uygulamasını daha iyi bilecek bilhassa sinif ögretmenliği yapacak kişinin bu alanda daha önce sinıf ögretmenliği de yapması lazım, bu diğer öğretmenlikler için de geçerli Dolayısıla bu dersleri veren hocaların milli eğitim ile iş bilirliği en azından 3 sene 5 sene iş birliği yapmast ve bir öğretmenlik deneyimi olması lazım hatta benim önerdiğim modelde ĕgitim fakültesindeki hocaların kısmi zamanlı olarak milli eğitimde haftada üç saat beş saat derse girip gelmeleri gerekir, yani sahada ne olup ne bitiyor bunu görüp gelecekler ondan sonra da masa başında ona kafa yoracaklar." (RG)

- "Öğretim elemanlarının bir aön önce doçent, profesör olma uğraşlarl, bizleri, ünivesiteleri, unvanlart çok ama bilgileri yetersiz insanlar haline getiriyor. Özellikle belli bir unvandan sonra insanlar ögrenmeyi birakıyorlar, ögrenmeye kapalı hale geliyorlar." (BK)

- “Dünyada okul deneyimi öğretmenlik uygulaması çok önemlidir, çok değerlidir. Ben sını öğretmenliğine baklyorum okul öncesi deneyimi önüne gelene veriliyor, o hocanın da o işten hiç anladığ yok. Açık konuşmak gerekirse işte öğrenciler okula gidiyorlar, oradaki ögretmeni eğer bir dönüt veriyorsa veriyor, bir gözlem yapabiliyorsa yapıyor, öyle boş boş tabiri caizse geçiyor, halbuki dünyada bakıldığında doktorluk gibi görülüyor ögretmenlik tamam mi, sen izleyeceksin, gözleyeceksin, sonra sen uygulama yapacaksin, uygulama yaptıktan sonra hem üniversitedeki hocan hem oradaki hocan sana dönüt verecek."(YD) 
Sınıf öğretmenliği alanında doktora yapmış öğretim elemanı sayısı yetersizliğinden verilen eğitimler de yetersiz. Yeterli değil. Düşünmeyi öğrenen öğretmen adayları yetiştirmek gerekiyor.
- "Türkiye'de sınıf öğretmeni yetiştirecek kişilerin sınıf öğretmenliği alanında doktora yapması gerekli sını öğretmeni anabilim dalı başkanına bakıyorsun sınıf ögretmenliği alaniyla bir ilgisi yok demi, bu ciddi bir problem. Bu Türkiye genelinin bir problemi, o yüzden derhal bununla ilgili önlemler alınmall." (RG)

- "Bence sınıf ögrretmenliğinde ögrencilerimize ilk önce düşünceyi öğretmemiz gerekiyor. Doğru düşünebilmek. Biz maalesef her zaman ögretmenliği test çözmek gibi görüyoruz. Öğrenciye çok iyi test çözdüren birine ögretmen diyoruz." (SD)

Kendisiyle görüşülen öğretim elemanlarının yarısından fazlası kendi alanında uzman olan akademisyenlerin sınıf öğretmenliği programında derse girmesi gerektiğini, bu şekilde verilen eğitimin kalitesinin artacağı görüşündedir. Bu görüşten yola çıkarak sınıf öğretmenliği dersine giren uzman sayısının yetersiz olduğu görülmektedir.

Öğretim elemanlarının "Meslek hayatınız süresince sınıf öğretmenliği bölümündeki öğrenci profili ile ilgili görüşleriniz nelerdir?” sorusuna ilişkin görüşleri Tablo 7’de verilmiştir.

Tablo 7. "Meslek hayatınız süresince sınıf öğretmenliği bölümündeki öğrenci profili ile ilgili görüşleriniz nelerdir?" sorusuna verilen yanitlar

Üniversiteye giriş puanlarındaki düşüş sınıf öğretmenliği bölümüne gelen öğrencilerin de profilini düşürüyor.

Öğretmenlik mesleğine gösterilen değerdeki düşüş bu bölümü okuyan öğrencilerdeki profilinde de düşüşe neden olmaktadır.

Sınıf öğretmenliği bölümündeki kontenjan artışı ve öğrencilerin öğretmenlik bilincindeki düşüş öğrenci profilindeki düşüşe neden oldu.

Bayan öğrencilerin daha verimli, istekli ve idealist bir profil sergilediğini söyleyebilirim.

Hedeflerden yoksun öğrenci profili artmaya başladı.

\section{Sınıf öğretmenliğini para kazanmak amacıyla okumaya başlayan öğrenci sayısının artışı öğrenci profilinde düşüşe sebep olmaktadır.}

Üniversite sayısının artması üniversitelerde kozmopolitik ve kültürel karışımın yok olmasına neden oluyor.

Üniversite sayının artması öğrenci kalitesini düşürüyor.
- "Evet bilişsel alan dediğimiz puan olarak üniversiteye yerleşmek açısından da bir düşüş var. O puan gerçekten ögrencilerin profilindeki düşüşü yansitmaktadır. O puanlardaki düşüş sadece bilişsel alandaki bir düşüş olarak algılanması doğru değil. Çünkü aynı zamanda o bilişsel alandaki o düşüş bireyin duyusal ve psikomotor alandaki düşüşü de çok iyi bir gösterge. " $(A K)$

- "Son 20 yllda ögretmenlik mesleğinin kaybettiği dĕgerle öğrencilerin sahip olduğu değer paralel bir şekilde düşmektedir. (AK)

- "Üniversitenin kontenjanının artmaslyla ve tabi ki sıralamada bizim ögrrenci aldığımız dilim daha altlara doğru kayınca bu bilinci kaybettik. Ya ögrencilerimizin başarılı olması daha iyi yani KPSS de başarılı olmamız daha iyi sınıf ögretmeni yetiştiriyoruz anlamı çıkmasın. Yani profilde aşă̆

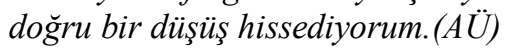

- "Şimdiye kadar derslerine girdiğim kadarıyla özellikle bayan öğrencilerin daha istekli olduklarını daha idealist göründüklerini söyleyebilirim. (AC)

- "Son zamanlarda son beş alt yıldır belki şu kayıp; hedeflerden yoksun bir ögrenci akışı var şu anda. Sadece ve sadece çevre baskislyla, üniversite bile okumak istemiyorlar, bir de alımlar çok arttı̆̆ için üniversitede artık normalde üniversitede olmak istemeyen insanlarl sinıf ögretmenliğinde görüyorum. Yani üniversite şu anda para kazanmak için bir yol olarak görüldüğü için böyle bir ögrenci profili var. "(BK)

- "Bunlar kazanabildikleri en iyi bölüme ya da alabildikleri en yüksek puanla gelmiş ögrenciler. Yani bir puan daha yüksek olsalardl buraya gelmeyeceklerdi veya sonunda bir meslek vaadi olmadan veya hayat kazanmak mecburiyetinde değilseniz hangi mesleği seçerdiniz sorusuna bunların hiç biri ögretmen olurdum yine de diyebilecek karakterde insanlar değil. Yani bunlardan böyle ideal bir öğretmen çıkmasını beklemiyorum. Bunlar ögretmenliği iaşe ibadesini temin edecek herhangi bir meslek gördüklerinden de toplumdan haksız olarak bekledikleri saygıyı da göremiyorlar. $(A \ddot{U})$

- "Her yerde bu bölüm olmasıyla birlikte öğrenci kendi bölgesi dışına çıkmayarak farklı kültürleri öğrenemediği için ileride verimsiz öğretmenlerin çıkmasına neden olacaktır. Atamalarla beraber farklı noktalara gidecek olan sınıf ögretmeni oralarda sıkıntı çekecektir. Bu sistemle bu değişmez. ” (GD) - "Üniversitelerin çok fazla açılmaslyla birlikte ögrenci profilinde düşmeye neden oldu. Gerçi sadece buna bağlayamayız. Diğer bir nedeni ise şudur, kriz dönemlerinde ögretmenlik garanti meslek olduğu için ögrenci profili yükseliyor. Diğer dönemlerde alımların olmamasına bağll olarak ta ögrenci profili düşüyor. (GD) 
Eğitim fakültesine daha çok kırsal kesimden gelen öğrenci çoğunlukta olduğundan iletişime daha kapalı öğrenci profili var.
- "Daha çok sınıf öğretmenliği kökenine bakacak olacak olursak kırsal alandan, orta kesimin alt tabakasina geçmeye çalışan kesimler tarafindan oluşturulan bir meslektir. Yine düz memur çocuklarının tercih etmiş olduğu bir meslektir. Bu nedenle sinıf öğretmenliğinde aldıkları ĕgitime răgmen toplumun bütün kesimleriyle aynı oranda iletişim kurduklarını düşünmüyorum." (GD)

Kendisiyle görüşülen öğretim elemanlarının yarısına yakını sınıf öğretmenliği bölümündeki kontenjanların ve ülke genelinde üniversite sayılarının artmasının sınıf öğretmenliği bölümüne gelen öğrencilerin düșük profilde olmasına, üniversiteye giriș puanlarının düșmesinin ve öğrencilerin öğretmenlik bilincindeki düşüşün öğrenci niteliğinin azalmasına neden olduğu görüşündedir. Bunun yanı sıra kimi öğretim elemanları da ülke genelinde üniversite sayısının artmasının üniversitelerdeki kozmopolit yapının bozulmasına neden olduğu ve kültürel karışımın yok olmaya başladığına, farklı kültürlerle kaynaşmayan, farklı kültürleri tanımayan öğrencilerin ileride niteliği düşüreceğine dikkat çekmektedir.

Öğretim elemanlarının "Sınıf öğretmenliği anabilim dalında yeterli nitelikte öğretim elemanının olduğunu düşünüyor musunuz?” sorusuna ilişkin görüşleri Tablo 8'de verilmiştir.

Tablo 8. Sınıf öğretmenliği anabilim dalındaki öğretim elemanlarının niteliğine ilişkin öğretim elemanı görüşleri

\section{Sınıf öğretmenliği bölümünde yeterli nitelikte öğretim elemanının olduğunu düşünüyor musunuz?"}

EVET

HAYIR (AK, AÜ, AC, BK, EY, RG, $\mathrm{SD}, \mathrm{SÇ}, \mathrm{YD}, \mathrm{GD})$

- "Her insanın uzman olduğu alanda görev alması, uzman olduğu derse girmesi çok daha yararlı olacaktır. Hiç ögretmenlik yapmamış çok iyi bir fizik dalında profesörü ya da matematik alanında bir profesörü getirip eğitim fakültesinde görevlendirmenin çok yanlış olduğu kanaatindeyim. Hiç öğretmenlik yapmamış, ögretmenliğin ne olduğunu bilmeyen insanlar bilim olarak çok iyi olabilirler. Belki dünyada bir iki numaradadırlar. Ama eğitim fakültesinde görevlendirilmeleri hiç doğru olmaz düşüncesindeyim.” (AK)

- "Hayır düşünmüyorum. Sinıf ögretmenliği bölümü biraz önce söylediğim gibi sanki aspirin gibi hocalar da başka alanlardan gelme. Geçici çözümleriz biz sınıf öğretmenliği için.” (BK) - "Belki de eğitim fakültesindeki en sorunlu bölüm sınıf ögretmenliği. Çünkü sınıf ögretmenliğindeki derslerin çeşitliliği çok fazla. Çok fazla olduğu için de bu derslerin her biriyle ilgili uzman öğretim elemanı bulmak çok zor. Dolayısıla ilgili ilgisiz herkes her derse girebiliyor. Onun için ögretim elemanı ile ilgili çok ciddi sıkıntılar var diyebilirim." (SÇ)

- "Üniversite hocasında olması gereken meziyet, çocuğa bilgi değil ufuk kazandıran, çocuğa rehberlik eden, çocuğun neyi nerede bulacă̆ını, nasıl bulacağını öğreten adam ama işte o niteliklerde zaylflama, kalitede düşüş olduğundan dolayı çocuk bu tür bir ögretmen prototipine feci halde karşı. Sen dersini anlat ya da bana sınavda soracă̆ın şeylerden bahset' beklentisinde olduğundan dolayı ögretmenin ya da buradaki ögretim üyesi elemanının niteliğini tartışmak aslında boşboğazlık bana göre." (AÜ)

-“Gerçekten sınıföğretmenliği bölümünde yüksek lisans, doktora yapmış hoca sayısı çok çok az ve bu iki taraflı olmall. Sinıf ögretmenliği hocalarının en az yarısi yüksek lisans ve doktoralarını sınıf ögretmenliği alanında yapmış olması lazım. Diğer yarısı, alan dersi mesela bir sınıf ögretmenliği alanında doktora yapmış arkadaş çok iyi bir fizikçi olmaz. Onun için bir fizik hocasl gerekebilir, bir edebiyat hocası gerekebilir ama hocaların yarısı sınıf ögretmenliği mezunu olması lazım ve yine de ek olarak bu sinıf ögretmenliği mezunu olan, yüksek lisans, doktora yapmış hocaların bir kaç yıllık ögretmenlik tecrübesi de olmall. Sadece teorik kalmamalart için.... Bu yüksek lisans, doktora programlarının yetersiz takip edilmesi, bir an önce doçent, profesör olma uğraşları bizi, üniversiteleri, unvanları çok ama bilgileri yetersiz insanlar haline getiriyor ve özellikle belirli bir unvandan sonra insanlar ögrenmeyi bıraklyorlar, ögrenmeye kapalı hale geliyorlar. Yani böyle bir gelişim problemimiz var." (BK)

- "Her yere eğitim fakültesi açarsanız nitelikli elaman dolduramazsınız diyorum, ki sınıf ögretmenliğine baklyorsunuz sınıf ögretmenliğinde doktora yapmış kimse yok. Biz nasıl bunlardan iyi bir sını öğretmenleri yetiştirmelerini bekleyebiliriz ki genel olarak bu bizim fakülte için geçerli değil. Türkiye 'de bizim fakülteden geride olan çok fakülte var." (RG)

Kendisiyle görüşülen öğretim elemanlarının sınıf öğretmenliği alanında doktoralı öğretim elemanlarına ihtiyaç olduğu, başka branştaki hocaların derse girmesiyle geçici çözümler bulunduğunu, başka bir taraftan da sınıf öğretmenliğinin bütün alanlarına hitap edecek bir şekilde akademik kariyer yapacak öğretim elemanı yetiştirmenin mümkün olmadığı görüşünde olduğu görülmektedir. Genel anlamda 
bu konuyla ilgili çıkarılan sonuç sınıf öğretmenliği alanında uzmanlık yapmış öğretim elemanlarına ihtiyaç duyulduğu yönündedir.

Öğretim elemanlarının "Sınıf öğretmenliği programında yer alan dersler öğretmenlik alan bilgisi, genel kültür ve öğretmenlik meslek bilgisi alanlarında öğrencilerde ne gibi değişiklikler yaratıyor?" sorusuna ilişkin görüşleri Tablo 9'da verilmiştir.

Tablo 9. Sınıf öğretmenliği programının öğretmen adaylarının niteliğine etkisine ilişkin öğretim elemanı görüşleri

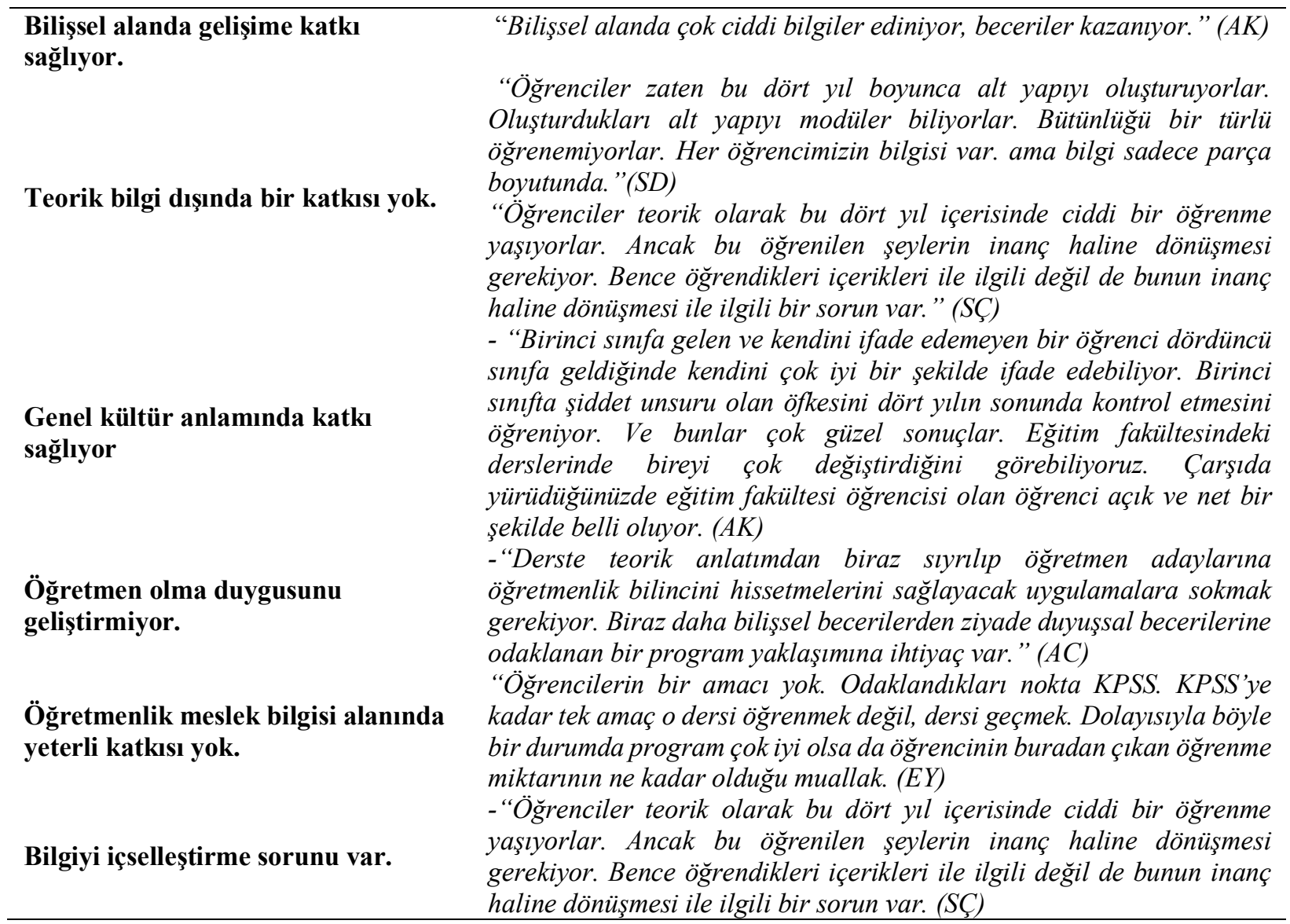

Tablo 9'da görüldüğü gibi, kendisiyle görüşülen öğretim elemanlarının görüşünden yola çıkıldığında sınıf öğretmenliği programında okutulan derslerin genel kültür alanında, bilişsel ve teorik anlamda gelişime katkı sağladığı, ancak öğretmenlik meslek bilgisi alanında çok boyutlu bir tesir bırakmadığını söylemek mümkündür.

Öğretim elemanlarının sınıf öğretmenliği eğitiminin niteliğinin artırılmasına yönelik "Sınıf öğretmenliğinde ilk müdahale edilmesi gereken alanlar/konular nelerdir? sorusuna ilişkin görüşleri Tablo 10 'da sunulmuştur.

Tablo 10. Öğretim elemanlarının sınıf öğretmenliğinde ilk müdahale edilmesi gereken alanlar/konulara ilişkin görüşleri

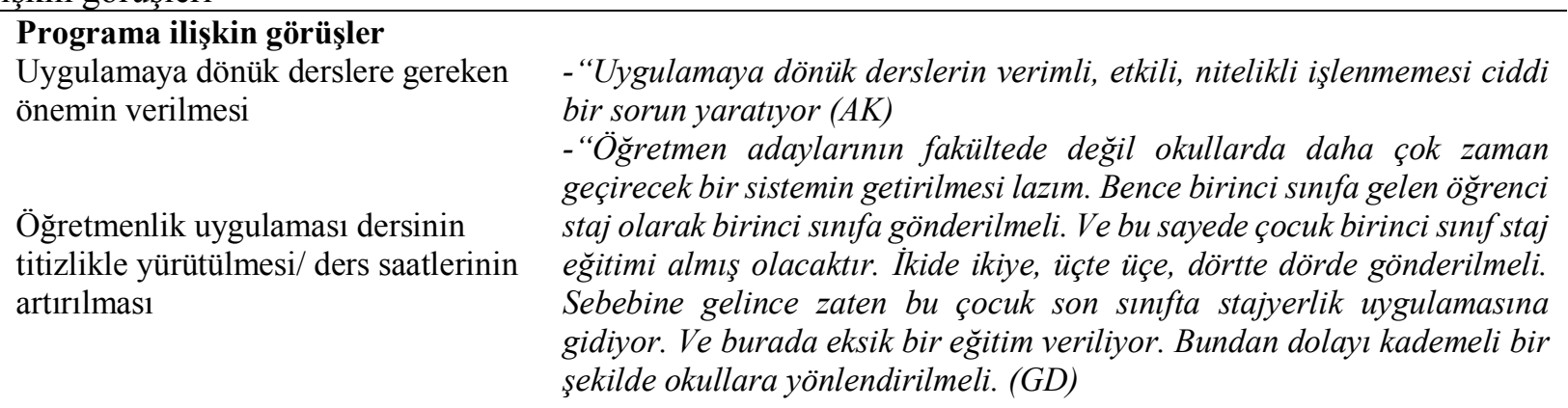


Son sınıf öğrencisinin yılın tamamını MEB' e bağlı okullarda geçirmesi

Eğitim Fakültelerine kendi sınıf öğretmenliği programlarını özgün olarak geliştirme yetkisi verilmesi

Programdaki gereksiz derslerin çıkarılarak daha işevuruk derslerin programa eklenmesi

Dönemlik popüler konulara (Değerler eğitimi vs.) yönelik dersler yerine evrensel konulara odaklı derslerin programa eklenmesi

Ders saatlerinin azaltılması/içeriklerinin sadeleştirilmesi/ders içeriklerinin gözden geçirilmesi

Ortak konuları barındıran derslerin birleştirilmesi

Oryantasyon tabanlı birinci sinıf dersleri eklenmeli

Argümantasyona dayalı, otantik öğrenme ortamları/durumları yaratilmalı.

\section{Programa giriş ve mezun olma koşullarına ilişkin görüşler}

- "Ders geçme sisteminin çok yanlış olduğu kanaatindeyim. Ve bizde ciddi bir anlamda eksiklik yaratıyor. Bizim şu an daha yeni 40 alan ögrencinin geçmesi 100 ameliyattan 40 tanesini başarll yapan bir doktora benzetmek yanlış olmaz. Bir doktor hata yaparsa hastası ölür bu bir kişidir. Bir ögretmen bir hata yaparsa yetiştirdiği nesil ölecektir... "Ĕ̈itim fakültesine giren her şahsın mezun olması doğru bir şey değil. Ĕ̆er eğitim fakültesine giren her ögrenci mezun olabiliyorsa 4 yılda hem de beşleyen yok. O zaman demek ki herkes mükemmel. O zaman gerek yok sinav yapmaya ders anlatmaya. Bırakalım ögrencilerimiz gitsinler uzaktan eğitim yoluyla alsınlar. Bu uzaktan eğitim yoluyla yapılacak bir iş değil maalesef." (AK)

- "Her yılsonunda başarısız olan öğrencilerin eğitim fakültesiyle ilişiğinin kesilmesi kanaatindeyim. Herkes öğretmen olmak zorunda değil. Ama
Eğitim fakültesindeki not geçme sisteminin değişmesi dönem öğretmenlerin yardımclsı olarak aktif olarak o işin içinde olması demektir. Yani haftada altı saat olarak değil o tozu tamamen yutarak tüm zamanını okulda geçirmesi lazım, yani sahada olması lazım” (YD) olarak geliştirme yetkisi verilmeli. Böylece bir serbest rekabet ortamı oluşur. Hangi eğitim fakültesi nasıl olur, çok güzel örnekler ortaya çıkar. Ayrıca tek kalıptan çıkmış gibi öğretmenler yetiştirmeyiz. Bunun Adlyaman Üniversitesi ne yaparsak yapalım çok yüksek puanla ögrenci alan bir yer haline gelmez. Neden? Serbest rekabet yok. Aynı planı kullanıyoruz, aynı müfredatı kullanıyoruz. Aynı müfredatı kullandığımızda eğitim fakültesiyle hiç bir zaman Adıyaman yarışamaz." şeklinde görüş belirtmişlerdir.” (BK)

yazmasını bilmeyen öğretmen adaylarımı var maalesef. Bu anlamda bir diksiyon dersinin kesinlikle konulması gerekmekte. Bir de bir ders olarak velilerle iletişim diye de bir ders konulmalı. (GD)

- Biraz daha evrensel, ögrenmeyi ögrenmeye yönelik derslerin konulmas yetiştirirken 4.sınıfa geldiğinde 1.sınıfta edindiği bilgiler artık eskimiş oluyor. Bu anlamda ögrenme becerisi edinmek adına bazl derslerin konulmasinda yarar görüyorum. (AK)

şeyi bilen sinıf ögretmeni yetiştirme çabası söz konusu oluyor. Ĕ̈itim denince akla ilk gelen sını ögretmenliği oluyor. Dolayısıla çok fazla çeşit ders olması bu derslerin de etkili verilememesi sorundur bence.
Dolayısıla ders saatleri değil de derslerin içeriklerinin değisstirilmesi belki de bu sorunu çözer diye düşünüyorum. (SÇ)

-Derslerin içeriklerinin gözden geçirilmesi lazım, haftalık ders saatlerinin yeniden incelenmesi lazım. Cünkü bazı dersler var gereksiz ya da haftalık - "Yani ders olarak mesela ilk iki senedeki derslerin çoğu lüzumsuz. Lisede gördükleri genel kültür derslerin, sayısal derslerin tekrarı olan dersler uygulaması olarak, sayısal dersler birleştirilebilir. Mesela temel matematik dersi de matematik ögretimi dersi içerisinde yer alabilir. (BK) - "Oryantasyon tabanlı birinci sinıf dersleri eklenmesi gerekiyor. Seçmeli derslerin ögrencilerimize faydal ve güncel olmast gerekiyor. Diger
derslere yönetmelik gereğ $i$ müdahale edemiyoruz ama seçmeli dersleri ögrencilerle açmak gerekiyor. Ĕğer bugün dün öğrettiğiniz gibi ögretiyorsanız yanlı öğretiyorsunuz demektir. Biz on yıldır aynı dersleri isliyoruz." (SD)

Okullarda daha çok otantik, gerçek yaşam, gerçek ögrenci problemleri, okul problemleri, bunların bir araya toplanıp ögrencilerle tartışılıp argümantasyon süreçleri ögretmen adaylarına yaşatılmalı.

- "Öğrenci dördüncü sınıfa geldiğinde fakültede işi olmayacak staj gördüğ̈̈ okulda oranın artık bir stajyeri olacak biz onu oradaki işlemleri 
Programa giriş koşullarının değişmesi

Mezun öğrencilerden dönüt alınarak programın niteliğinin tespit edilmesi

Sınıf öğretmenliğini seven adayların bu bölüme girmesinin teşvik edilmesi

Öğretmen adaylarına kitap okuma, kaynak materyal kullanma vb. zorunluluk getirilmesi/özendirilmesi

Öğretmen atamalarında mülakat sisteminin uygulanmasi

Sinıf mevcutlarının azaltılması

\section{Programdaki öğretim elemanlarının niteliğine ilişkin görüşler}

"Sınıf öğretmenliği sürekli gelişen ve kendini yenileyen bir meslektir. Ögretmen adaylart maalesef kendilerine bir şey katmadan yollarına devam ediyorlar. Dediğim gibi kırsal kesimden geldikleri için materyal ve yayınlara pay ayıramıyorlar. Bundan dolayı okul bittikten sonra kişisel gelişim kitaplarını eğitim kitaplarını okumaları gerekiyor. Fakat bunu yapmadıklarından dolayı olmuyor." (GD)

- "Öğretmenlik sınavı kaldırılmalı, buna tarafız bir kurul karar vermeli. Fakülteyi bitirdikten sonra, stajl bittikten sonra bundan ögretmen olabilecek adam çıkar mı diye bir kurulun karar vermesi gerekir. Bu kurulun içinde psikolog, sosyolog, eğitimci, alan uzmanı, programcı yer almall. Böyle geniş bir komisyonun karar vermesi, bundan ilkokul ögretmeni çıkar mı diye karar vermesi gerekir. Öğretmeni seçerken düzgün, toplumu kabullenmiş, öğretmenliği kabullenmiş bireyleri seçmek

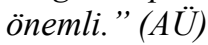

Ilk müdahale edilmesi gereken sorunlu nokta, sınıf mevcutlart. Çok fazla öğrenci alıyoruz. Bu bizim iyi öğrenci yetiştirme konusundaki performansımızı düşürüyor" (BK)

- "Bence bu programın uzman olan kişilere birakılması gerekiyor. Sinıf ögretmenliği ile ilgili kongrelere gidiyorum sinıf öğretmenliği alanında doktor olanları görmüyorum, diğer yan dal çakma alanlardan sinıf ögretmenliğine geçenler var. Yani gerçekten bu alanda kendini yetiştirmiş insanlara bırakılması gerektiğini düşünüyorum. Şu anda Türkiye' de sınıf öğretmenliği alanında kendini yetişirmiş Profesör çok az yani jürileri kuramıyorlar, sıkıntı yaşıyorlar belki bir ilerleme olabilir." (RG)

\section{Fakültedeki uygulamalara ilişkin görüşler}

Alanda nitelikli ve uzman hocaların programda görevlendirilmesi

Her fakülteye bir uygulama okulu yapilmali.
"Her eğitim fakültesine bir uygulama okulu, bir tatbikat mektebi yapılmall" $(A \ddot{U})$

Kendisiyle görüşülen öğretim elemanlarına göre, sınıf öğretmenliğinde ilk müdahale edilmesi gereken konuların başında sınıf öğretmenliği programında öğretmenlik uygulaması ve uygulamalı derslerin sayısının artırılması, bu derslere gereken önemin verilmesi ve ders içeriklerinin gözden geçirilmesi, sınıf mevcutlarının azaltılması yer almaktadır. Sınıf öğretmenliği programında görevli olan öğretim elamanlarının sınıf öğretmenliği alanında uzman olmamalarının bölümün kalitesini düşürdüğünü vurgulayan öğretim elemanları, nitelikli öğretim elemanlarının sınıf öğretmenliği anabilim dalında görevlendirilmesi gerektiğine dikkat çekmişlerdir. Bu konular çerçevesinde sınıf öğretmenliğinin geleceği için çalışmalar yapılması gerektiği söylenebilir. 


\section{TARTIŞMA ve SONUÇ}

Araştırma sonucunda öğretmen adaylarının yarısından fazlasının sınıf öğretmenliği bölümünü isteyerek tercih etmediği ortaya çıkmıştır. Atanma kaygısının daha az olması ve diğer bölümlere göre istihdamı kolay olan bir meslek olması nedeniyle bölümü tercih eden öğretmen adaylarının sayısı oldukça fazladır. Araştırmanın bu bulgusu Aydoğmuş ve Yıldız (2016)'ın öğretmen adaylarının sınıf öğretmenliği bölümüne isteksiz olarak geldikleri; aile baskısı, başka bölümlere yerleşmek için yeterli puanı alamama, kendi memleketinde okuma isteği, atanma sıkıntısı olmaması gibi gerekçelerle bölümü tercih ettikleri bulgularıyla örtüşmektedir. Ayrıca bu araştırmanın öğretmen adaylarının öğretmenliği istihdam olanağının fazla olması, aile ve çevre baskısı, üniversite sınavından alınan puan gibi nedenlerle tercih ettiğine yönelik bulgularıyla örtüşen pek çok araştırma (Aksu ve diğerleri, 2010; Ok ve Önkol, 2007; Okçabol ve diğerleri, 2003; Orhan ve Ok, 2014; Özsoy, Özsoy, Özkara ve Memiş, 2010; Ubuz ve Sar1, 2009) mevcuttur.

Öğretmen adaylarının sınıf öğretmenliği bölümünü yüksek oranda seçme durumları, bölüme ilişkin olumlu tutumlara, ilgi ve isteğe sahip olarak bölüme geldikleri anlamına gelmemektedir. Zorunluluktan dolayı bu bölümü seçme oranlarının yüksek olması, bölüme girmeden önce öğretmen adaylarının merkezi yerleştirme sınavlarının yanı sıra bölüme ilişkin ilgi ve yeteneklerinin belirlenmesini sağlayacak farklı ön seçim kriterleri konulmasını zorunlu kılmaktadır. Hizmet öncesinde öğretmen adaylarının mesleğe yönelik olumsuz tutumları, hem aldıkları hem de sunacakları eğitimin kalitesini olumsuz etkileyecektir. Oktay (1991) öğretmen adaylarının mesleğini isteyerek seçip seçmeme durumlarının onların hizmet öncesi aldıkları eğitimin niteliğini ve meslek sırasındaki başarısını etkileme yönünden son derece önemli olduğunu ifade etmiş̧ir. Turhan, Demirli ve Nazik (2012) de öğretmenlerin mesleği sevme, değer verme düzeyinin mesleki adanmışlık düzeyine olumlu etki yaptığını; mesleğin toplumsal statüsünü düşük bulmanın mesleki adanmışlık düzeylerini olumsuz etkilediğini belirtmiştir.

Araştırmanın önemli bulgularından biri öğretmen adaylarının, derslerin uygulamaya yönelik işlenmesinin kendilerine daha fazla katkı sağladığına inanmalarıdır. Öğretmenlik uygulaması dersinin titizlikle ve ciddi bir biçimde yürütülmesi gerektiği de araştırmada ulaşılan önemli sonuçlardan biridir. Araştırmanın bu sonuçları öğretmenlik uygulaması dersinin yararlı ve işlevsel bulunduğu pek çok araştırmanın (Demircan, 2007; Kılınç ve Gödek Altuk, 2010; Özay Köse, 2014; Saracaloğlu, Yılmaz, Çöğmen ve Şahin, 2011) sonuçlarıyla örtüşmektedir. Bu araştırmada programda alana katk1 sağlamayacak çok fazla dersin olduğu, alan bilgisi derslerinin sayısının yetersiz; genel kültür, alan bilgisi ve öğretmenlik meslek bilgisi ders saatlerinin dağılımının orantısız olduğu yönünde görüşler de ortaya çıkmıştır. Alanyazında araştırmanın bu sonuçlarını destekleyen pek çok çalışmaya rastlanmıştır. Ateş ve Burgaz (2014) okul deneyimi ve öğretmenlik uygulaması derslerinin yetersiz olduğunu vurgulamıştır. Şahin ve Kartal (2013) tarafından yapılan araştırma sonunda sınıf öğretmeni adaylarının derslerin uygulamaya dayalı olarak yürütülmesinin öğretmenlik becerilerini kazandırma bakımından daha etkili olduğu düşüncesine sahip olduğu ortaya çıkmıştır. Okçabol (2004) tarafından yapılan araştırmada, öğretmen adaylarına göre öğretmenlik mesleği ile ilgili teorik ve uygulamaya dayalı derslerin yeterli olmadığı; Öztürk ve Yıldırım (2014) tarafından yapılan araştırmada da öğretmen adaylarının eğitim fakültesinde aldıkları derslerde kuram ve uygulama arasında denge olmadığı yönünde görüşlere sahip olduğu ortaya çıkmıştır. Benzer biçimde Çoban (2011) da sınıf öğretmenliği lisans programında meslek bilgisi, genel kültür ve seçmeli derslerin dengeli dağılmadığını belirtmektedir. Elma ve Ergen (2016) tarafından yapılan araştırmada yeni mezun sınıf öğretmenlerinin sınıf öğretmenliği programında sınıf ve okul yönetimi, diksiyon, iletişim becerileri gibi derslere daha fazla gereksinim duydukları ortaya çıkmıştır. Bayındır (2015) tarafından yapılan araştırmada da öğretmen adaylarının büyük çoğunluğunun programdaki lisans derslerini kısmen yeterli bulduğu; öğretmen eğitimi programlarının öğretmen adaylarına etkili öğretmenlik becerilerinin kazandırılmasında yetersiz olduğu, programda teorik bilginin fazla olduğu ortaya çıkmıştır. Ayrıca öğretmen adaylarının etkili iletişim, hitabet ve diksiyon ile çocuklarla iletişim konusundaki dersleri daha fazla önemli buldukları Bayındır (2015) tarafından yapılan ve bu araştırmanın bulgularıyla örtüşen sonuçlarından biridir. Kennedy, Ahn ve Choi (2008) öğretmen eğitimi programlarında meslek bilgisi derslerine daha fazla önem verilmesi gerektiğini belirtmektedir. Sarıtaş (2007) tarafından öğretmen eğitimi programlarının öğrencilerin eğitim yaşamları boyunca edindikleri kuramsal bilgileri uygulamaya dönüştürecek gerekli ortamı sağlamadığı vurgulanmaktadır. Yılmaz ve diğerlerinin (2017) öğretmen 
yetiştirme programlarının içerik ve uygulamalarının güncellenmesi ve derslerin kuram ve uygulama boyutlarının dengelenmesi yönündeki önerileri de bu araştırmanın sonuçlarını desteklemektedir.

Dünyadaki öğretmen yetiştirme sistemleri incelendiğinde, öğretmen adaylarına uygulanan hizmet öncesi eğitim programlarının niteliği artırmada büyük rol oynadığı dikkat çekmektedir (Işık, Çiltaş ve Baş, 2010: 54). Nitelikli bir öğretmen eğitimi, öğretmenin mesleğin gereklerini yerine getirmesini ve buradaki zorluklarla yüzleşmesini sağlayacak ve yetkilendirecek programlara bağlıdır. Bu nedenle öğretmen adaylarının yeteneklerini keşfetmelerine, fiziksel ve zihinsel potansiyellerini tam anlamıla gerçekleştirmelerine, toplumda sorumlu bir vatandaş olarak görevlerini yerine getirmeleri için gereksinim duyulan sosyal ve insani değerlerini geliştirmelerine olanak sağlayan öğrenme durumlarının öğretilmesini destekleyici bir vizyon taşıyacak biçimde öğretmen eğitimi programlarının güncellenmesi gerekmektedir.

Ülkelerin eğitim kalitesi yetiştirilen öğretmenlerin kalitesiyle doğru orantılıdır. Bu nedenle öğretmen eğitiminin niteliği ve niteliği artırmak amacıyla gerçekleştirilecek reformlar pek çok ülkede tartış1lan önemli konular arasındadır (Adeousun, 2011; Calderhead, 2001; Hoban, 2004). Öğretmen eğitimi programlarıyla ilgili en büyük tartışma konusu ise programın önemli bir kısmının içeriğe mi yöntemtekniğe mi odaklanması gerektiği üzerinedir. Tom (1997) belirsiz hedefler, birbiriyle ilgisiz ve tutarsız parçalı dersler, farklı fakültelerde yer alan aynı içerikli dersler arasındaki tutarsızlık, üniversitede alınan derslerle okullardaki uygulamalar arasında bağlantı olmaması, eğitim fakültesindeki öğretim elemanlarının nitelikli olmayışı, bölümler arasında işbirliği eksikliği, öğretmenlerin öğretmenlik uygulamasındaki denetim rollerinde yaşanan belirsizlikler, öğretmen eğitimine katılan paydaşların çok fazla olması, değişim stratejilerini planlama eksikliği ve öğretmen eğitiminin süreklilik göstermeyen reformlara karş1 savunmasızlığı gibi birçok öğretmen eğitimi programında sorun teşkil eden on konu belirlemiştir. Hoban (2004) da bu sorunlara üniversiteler ve okullar arasındaki işbirliği eksikliğini eklemiştir. Bu sorunların çözümüne yönelik gerçekleştirilecek tüm reformlar öğretmen eğitiminin niteliğini artırmaya büyük katk1 sağlayacaktır.

Araştırma sonucunda, öğretmen adaylarının büyük çoğunluğunun, derslerine giren öğretim elemanlarının yeterli donanıma ve niteliğe sahip olmadığı görüşünde olduğu ortaya çıkmıştır. Öğretmen adayları, aldıkları öğretmen eğitimini "yetersiz" olarak görürken, öğretim elemanlarının da akademik olarak yetersiz, ilgisiz, isteksiz ve etkileşime kapalı olduğunu düşünmektedir. Araştırmada ideal sınıf öğretmeni profilini oluşturma bakımından öğretim elemanlarının öğretmen adaylarını ilgili kaynaklara yönlendirme rollerine daha fazla vurgu yapılmış ve bu konuda öğretmen adaylarının daha fazla ilgi ve desteğe ihtiyaçları olduğu dile getirilmiştir. $\mathrm{Bu}$ araştırmanın öğretim elemanlarının yetersiz olduğu yönündeki bulguları, Dilshad (2010) ile Yılmaz ve diğerlerinin (2017) bulgularıla benzerlik göstermektedir. Yavuzer, Dikici, Çalışkan ve Aytekin (2006)'in sınıf öğretmenliği programındaki öğretim elemanlarının dersleri ilgi çekici biçimde sunmadıkları, derslerin hedeflerine uygun öğretim yöntem ve teknikleri kullanmadıkları yönündeki araştırma bulgusu da bu araştırmanın bulgularını desteklemektedir. Tunca ve diğerleri (2015) tarafından yapılan araştırma sonucunda da öğretmen adaylarının, öğretim elemanlarının mesleki gelişimi sağlama, sınıfi etkili yönetme, rehberlik ve danışmanlık yapma, öğrencileri tanıma ve duyarlı olma, istekli ve coşkulu olma gibi mesleki rol ve sorumluluklara sahip olmaları gerektiğini düşündükleri ortaya çıkmıştır. Ergün, Duman, Kıncal ve Arıbaş (1999) öğretim elemanlarının sahip olmaları gereken en önemli özelliğinin güleryüzlü olmak ve içtenlik olduğunu vurgulamaktadır. Benzer biçimde Özgüngör ve Duru (2015) tarafından yapılan araştırmada da öğretim elemanlarının öğrencilerle etkileşimde olma, alanında uzman, öğrencilere ve öğrenci gelişimine ilgi duyma, yaptığı işten haz alma, öğrencilerin mesleki gelişimini destekleme gibi özelliklere sahip olmaları gerektiği görüşünde oldukları ortaya çıkmıştır.

Araştırmanın önemli amaçlarından biri de öğretmen adaylarının aldıkları öğretmen eğitiminin niteliğinin artırılmasına ilişkin görüşlerinin belirlenmesidir. Bu kapsamda sınıf mevcutlarının kalabalık olması nedeniyle aldıkları eğitimin kalitesinin düşük olduğunu ve sınıf öğretmenliği programına öğrenci alımında kriterlerin yükseltilmesi gerektiğini düşünen öğretmen adayı sayısı oldukça fazladır. Ayrıca son yıllarda atanamayan öğretmen adayı sayısının artması ve öğretmen alımlarının azalmasından dolayı öğretmen adaylarının öğretmenlik mesleğine ilişkin algı ve tutumlarının olumsuz olduğu öğretmen adaylarının vurguladıkları önemli hususlardan bir diğeridir. Araştırmanın bu bulgularıyla paralel olarak 
Y1lmaz ve diğerleri (2017) öğretmen eğitimi programları için kontenjan belirlenmesinde kısa vadeli geçici çözümlere başvurulmasını öğretmen eğitiminin niteliğini etkileyen önemli bir sorun olarak görmekte, programlara kontenjan belirlenmesinde uzun vadeli planlamalar yapılmasını önermektedir. Benzer şekilde Elma ve Ergen (2016) tarafindan yapılan araştırmada da sınıf öğretmenliği eğitiminin niteliğinin artırılmasına yönelik katılımcıların programa alınan öğrenci sayılarının azaltılması, mevcut sınavların yanı sıra yetenek sınavları ve mülakatların yapılması yönünde önerilerin bulunduğu ortaya çıkmıştır.

Araştırmanın amaçlarından bir diğeri öğretim elemanlarının sınıf öğretmenliği eğitiminin niteliğinin artırılmasına ilişkin görüşlerini ortaya çıkarmaktır. Bu amaca yönelik ilk olarak öğretim elemanlarının ideal sınıf öğretmeni ve sınıf öğretmeni adayının ne tür özelliklere sahip olması gerektiğine ilişkin algıları belirlenmeye çalışılmıştır. Öğretim elemanlarının görüşünden yola çıkarak ideal sınıf öğretmeni ve öğretmen adayının; etkili iletişim ve disiplinler arası ilişki kurma becerisine sahip, çocukları seven ve onları tanıyan, sabırlı, programa ilişkin derin bilgisi olan, mesleğini seven ve sınıf öğretmenliğini birincil amaç edinen bir birey olması gerektiği görüşü ortaya çıkmıştır. Oktay (1991) da öğretmenliği diğer meslekler arasında aynı anda çok değişik rolleri birden yerine getirme zorunluluğu olan karmaşık mesleklerden biri olarak görmekte; öğretmenin sınıfta lider, plan ve program yapma, çocuk ve gençlere model olma, toplumun kalkınmasında itici güç olma, etkili iletişim kurma gibi niteliklerinin bulunduğunu belirtmiştir. Kahramanoğlu ve Ay (2013) sınıf öğretmenlerinin birden fazla dersten sorumlu olmaları nedeniyle yeterlikler bağlamında diğer branş öğretmenlerinden ayrıldığını, sınıf öğretmenlerinin disiplinlerarası anlayışa dayalı yeterliklere sahip olmaları gerektiğini belirtmektedir. Çelikten, Şanal ve Yeni (2005) öğretmenlerin gelişimlere açık olma, kendini sürekli yenileme, toplumsal değişmeleri anlayıp yorumlayabilme, etkili iletişim kurabilme gibi niteliklere sahip olması gerektiğini ifade etmektedir.

Araştırmada öğretim elamanları tarafından son yıllarda sınıf öğretmenliğindeki kontenjan artışının sınıf öğretmenliğindeki öğrenci niteliğinde düşüşe neden olduğu belirtilmiştir. $\mathrm{Bu}$ bakımdan sınıf öğretmenliği bölümüne öğrenci alımlarının azaltılması, işini seven ve ciddiye alan kişilerin bu bölüme gelmesi gerektiği vurgulanmıştır. Oktay (1991) da mevcut üniversite seçme sisteminin, öğrencilere yetenek, ilgi ve isteklerine uygun alanlara girebilme hususunda uygun firsatlar vermediğini, puanları hukuk, iktisat, işletme, mühendislik, tıp gibi alanlara girmeye yeterli olmayan adayların açıkta kalmamak için öğretmen yetiştiren kurumları tercih ettiklerini ve diğer bölümlere girememenin kırıklığı ile derslere yeteri kadar ilgi duymadıklarını, bu nedenle de öğretmenliğin son yıllarda önemli ölçüde değer kaybettiğini vurgulamaktadır. Çelikten, Şanal ve Yeni (2005) de öğretmenlik mesleğine nitelikli ve istekli öğrencilerin alınmasının ve ortaöğretimden iyi derecelerle mezun olan gençlerin öğretmenlik programlarını tercih eder duruma getirilmelerinin öğretmenlik mesleğinin statü ve kalitesinin artırılmasına büyük katkı sağlayacağını belirtmektedir.

Öğretim elemanlarına göre fakültede verilen eğitim ideal sınıf öğretmenini yetiştirmede yetersiz kalmaktadır. Sınıf öğretmenliği programında derslere girecek yeterli sayıda alanında uzmanlaşmış öğretim elemanı bulunmadığından öğretmen adayları derslere giren öğretim elemanlarından yeterli verimi alamamaktadır. Bu da sınıf öğretmenliği alanında uzmanlaşmış öğretim elemanlarına ihtiyaç duyulduğunu göstermektedir.

Öğretmen eğitimcileri, öğretmen eğitimi programlarının kalitesinin iyileştirilmesinde ve geliştirilmesinde önemli rol oynamaktadır. Bu nedenle onların programa ilişkin yargı ve algılarının belirlenmesi önem taşımaktadır (Dilshad ve Iqbal, 2010). Bu araştırmada öğretim elemanlarına göre sınıf öğretmenliği programında müdahale edilmesi gereken ilk alanlar arasında not geçme sisteminde değişiklik olması ve öğretmenlik uygulaması dersine ağırlık verilmesi gerektiği ön plana çıkmaktadır. Sınıf öğretmenliği programında okutulan derslerin öğretmen adaylarına yeterli oranda katkı sağlamadığ1 öğretmen adayları gibi öğretim elemanları tarafından da vurgulanmıştır. Programda gereksiz ders sayısının çok olduğu, bunun yerine faydalı ve nitelikli derslerin programa konulması gerektiği öğretim elemanlarının görüşlerine göre ortaya çıkan önemli diğer sonuçlardan bazılarıdır. Sınıf öğretmenliği programında uygulamalı ders saatlerinin az olduğu, bu derslere daha fazla ağırlık verilmesi gerektiği görülmektedir. Öğretim elamanlarının görüşlerine göre ders saatlerinin çokluğu ve ders içeriğindeki düzensizlikler sınıf öğretmenliğindeki ilk müdahale edilmesi gereken konulardan bazılarıdır. Araştırmanın bu sonuçlarını destekler nitelikte Topkaya, Tokcan ve Kara (2012) da öğretmen adayların hizmet öncesi almış oldukları 
eğitimin teoriye dayalı olduğunu ve alınan bu teorik bilgilerin gerçek sınıf ortamında öğretme faaliyetleri ile pek fazla ilişkilendirilmeden verildiğini belirtmektedir. Arslanoğlu (2005) tarafından yapılan araştırmada öğretmen, öğretmen adayları ve öğretim elemanlarının öğretmen eğitiminde kuram ve uygulama arasında güçlü bir denge bulunması ve derslerin uygulamalı bir biçimde yürütülmesi görüşünde oldukları ortaya çıkmıştır. Benzer şekilde sınıf öğretmenliği lisans programının öğretim üyeleri ve öğretmen adaylarının görüşleri doğrultusunda değerlendirilmesini amaçlayan Taş, Kunduroğlu-Akar ve Kıroğlu (2017) tarafindan yapılan araştırma sonucunda da katılımcıların öğretmen eğitimi programlarından bazı derslerin çıkarılması, bazılarının birleştirilmesi, içerik kategorilerinin değiştirilmesi ve öğretmenlik uygulamasına daha fazla önem verilmesi gibi öneriler sundukları ortaya çıkmıştır. Ayrıca Altuner Baskan, Aydın ve Madden (2006)'nın yaptığı araştırma sonucunda ülkemizde uygulanan öğretmen yetiştirme modeli, yabancı ülkelerde uygulanan öğretmen yetiştirme politikaları ile mukayese edilmiş ve öğrenci seçme ve yetiştirme süreci, öğretmen istihdamı şartları gibi boyutlar çerçevesinde karşılaştırmalar yapılmıştır. Yapılan çalışma sonucunda öğretmen eğitimi programlarında genel kültür, öğretmenlik meslek bilgisi ve öğretmenlik uygulaması gibi derslerin az olduğu ortaya çıkmıştır. Araştırma sonucunda ülkemizde eğitim fakültelerine öğretmen adayı seçme ve öğretmen eğitimi sürecinin akademik ve teknik olarak yeniden düzenlenmesi gerektiği dile getirilmiştir.

Araştırmada sınıf öğretmenliği alanında uzman öğretim elemanı eksikliği, mezun olan öğrencilerden dönüt alamama gibi eksiklikler öğretim elemanları tarafından sıkça vurgulanan temalar olarak karşımıza çıkmaktadır. Öğretim elemanlarının görüşünden yola çıkarak son yıllarda sınıf öğretmenliği programına yerleşen öğrenci profilinin düşük olduğu, bu bakımdan sınıf öğretmenliği programına alım kriterlerinin gözden geçirilerek artırılması ve üniversiteye giriş sınavının yanında programa yerleşecek öğretmen adayının bilişsel, duyuşsal, psikomotor gelişimi ve mesleğe yatkınlığı dikkate alınarak kendi alanında uzmanlaşmış bir heyet tarafından objektif bir şekilde mülakattan geçirilmesi gerektiği sonucu ortaya çıkmıştır. Araştırmanın bu bulguları Yılmaz ve diğerleri’nin (2017) öğretmen adaylarının seçiminin sınavlarla yapılması durumunda öğretmen niteliğinin artacağ1 yönündeki görüşleriyle örtüşmektedir.

Araştırma sonuçlarına dayalı olarak sınıf öğretmenliği eğitiminin niteliğini artırmaya yönelik şu öneriler getirilebilir:

- Sınıf öğretmenliği programı teori ve uygulama açısından dengeli hale getirilmek amacıyla gözden geçirilmeli ve geliştirilmelidir. Özellikle öğretmenlik uygulaması dersinin süresi artırılarak, beceri geliştirmeye odaklanılmalıdır.

- Sınıf öğretmenliği programında öğretmenlik meslek bilgisi derslerinin oranı daha fazla olmalıdır.

- Öğretmen adaylarının mesleki bilgi ve becerilerini artırmak amacıyla kapsamlı bir fakülte geliştirme programı hazırlanmalı ve uygulanmalıdır.

- Sinıf öğretmenliği programını öğretmenlik mesleğine yönelik olumlu tutum ve ilgiye sahip olan öğrencilerin tercih etmeleri teşvik edilmeli, başarılı öğrencilerin programa girişini sağlamak amacıyla ön seçim uygulamaları (mülakat, yetenek sınavı vs.) gerçekleştirilmelidir.

- Sınıf öğretmenliği programındaki derslerin alan uzmanı öğretim elemanları tarafindan verilmesi sağlanmalıdır.

- Öğretmen adaylarının istihdam edilmesinde öğretmen adaylarının mezun oldukları fakülteler de dikkate alınmalı, öğretmen eğitiminde kalite güvencesinin sağlanmasına önem verilmelidir. 


\section{KAYNAKLAR}

Adeosun, O. (2011). Teacher education programmes and the acquisition of the 21st century skills: Issues and challenges in Nigeria in CICE 4 Africa-Asia university dialogue for educational development. Report of the International Experience Sharing Seminar (2): Actual Status and Issues of Teacher Professional Development. 103-120.

Aksu, M., Demir, C. E, Daloğlu, A., Yıldırım, S. ve Kiraz, E. (2010). Who are the future teachers in Turkey. Characteristics of entering student teachers. International Journal of Educational Development, 30(1), 91- 101.

Akyol, H. (2011). Sınıf öğretmenliği eğitimi: Sorunlar ve öneriler. Ĕğitimci Öğretmen Dergisi, 2, 11-14.

Altuner Baskan, G., Aydın, A. ve Madden, T. (2006). Türkiye'deki öğretmen yetiştirme sistemine karşılaştırmalı bir bakış. Ç. Ü. Sosyal Bilimler Enstitüsü Dergisi, 15(1), 35-42.

Arslanoğlu, Ö. (2015). An examination of how the theory-practice relationship of pedagogy courses is conceived and perceived by the participants, and how management of education systems and faculties can enhance the quality of teacher education in Turkey. Unpublished doctoral dissertation, Durham University, Durham.

Ateş, H., \& Burgaz, B. (2014) Türkiye, ABD ve Finlandiya öğretmen yetiştirme sistemlerine ilişkin öğretmen adaylarının görüşleri ve Türkiye'deki sistemin geliştirilmesine ilişkin öneriler, Kastamonu Üniversitesi Kastamonu Ĕgitim Dergisi, 23(4), 1710-1722.

Aydoğmuş, M. ve Yıldız, M. (2016). Sınıf öğretmeni adaylarının öğretmen olmak istememelerinin nedenleri. Journal of International Social Research, 9(47), 587-600.

Bayındır, N. (2015). Sınıf öğretmeni adaylarının alan ile ilgili kurslara/ eğitimlere ilişkin beklenti durumlarının belirlenmesi. INES Uluslararası Eğitim Bilimleri Dergisi, 2 (5), 395-404.

Camelia, S. \& Elisabeta, P. M. (2013). Initial teacher training in Romania - a critical view. 5th International Conference EDU-WORLD 2012 - Education Facing Contemporary World Issues. Procedia - Social and Behavioral Sciences 76: $780-784$.

Calderhead, J. (2001). International experiences of teaching reform. In V. Richardson (Ed.) Handbook of research on teaching (4th Ed.). Washington, DC: American Educational Research Association.

Can, E. (2017). Öğretmenlik mesleği: mevcut durum ve uygulamalar. Ĕgitime farklı bakış. Babaoğlan, E., Kıral, E. Çilek, A ve Güçlü Yılmaz, F. (Eds.). Ankara: Eyuder Yayınları.

Craig, H. J., Kraft, R. J: \& Plessis, J. (1998). Teacher Development. Making an Impact. Usard, Advancing Basic Education And Literacy Project. https://people.umass.edu/educ870/teacher_education/Documents/Craigbook.pdf adresinden 20.01.2019 tarihinde alınmıştır.

Çelikten, M., Şanal, M. ve Yeni, Y. (2005). Öğretmenlik mesleği ve özellikleri. Erciyes Üniversitesi Eğitim Fakültesi. Sosyal Bilimler Enstitüsü Dergisi, 19(2), 207-237.

Çoban, A. (2011). Sınıf öğretmenliği lisans programının değerlendirilmesi. Dicle Üniversitesi Ziya Gökalp Eğitim Fakültesi Dergisi, 16(1), 28-45.

Demircan, C. (2007). "Okul deneyimi II dersine yönelik öğrenci görüşlerinin incelenmesi (mersin üniversitesi örneği)", Mersin Üniversitesi Ĕ̆itim Fakültesi Dergisi, 3(2), 119-132.

Desimone, L. (2009). Improving impact studies of teachers' professional development: Toward better conceptualizations and measures. Educational Researcher, 38(3), 181-199.

Dilshad, M. \& Iqbal, H. M. (2010). Quality indicators in teacher education programmes. Pakistan Journal of Social Sciences (PJSS), 30(2), 401-411.

Dilshad, R. M. (2010). Assessing quality of teacher education: A student perspective. Pakistan Journal of Social Sciences (PJSS) 30(1), 85-97.

Elma, C. ve Ergen, Y. (2016). Yeni mezun sınıf öğretmenlerinin sınıf öğretmeni yetiştirme programına ilişkin görüşleri. Kesit Akademi Dergisi, 2 (4), 185-211. Arslanoğlu, Ö. (2015). An Examination of How The TheoryPractice Relationship of Pedagogy Courses is Conceived and Perceived by The Participants, and How Management of Education Systems and Faculties can Enhance The Quality of Teacher Education in Turkey. (Yayımlanmamış Doktora Tezi). Durham University, Durham

Ergün, M., T. Duman, R. Kıncal \& S. Arıbaş. (1999). İdeal bir öğretim elemanının özellikleri. Afyon Kocatepe University Journal of Social Science, 3, 1-19.

Hanushek, E. A., Kain, J. F. \& Rivkin, S. G. (2004). Why public schools lose teachers. Journal of Human Resources, 39(2), 326-354.

Hattie, J. (2009). Visible learning a synthesis of over 800 meta-analyses relating to achievement. London: Routledge.

Hoban, G.F. (2004). Seeking quality in teacher education design: A four-dimensional approach. Australian Journal of Education, 48 (2), 117-133.

Işık, A., Çiltaş, A. ve Baş, F. (2010). Öğretmen yetiştirme ve öğretmenlik mesleği. Atatürk Üniversitesi Sosyal Bilimler Enstitüsü Dergisi, 14(1), 53-62.

Jamil, H. (2014). Teacher is matter for education quality: A transformation of policy for enhancing the teaching profession in Malaysia. Journal of International Cooperation in Education, 16(2), 181-196.

Kahramanoğlu, R. ve Ay, Y. (2013). Sınıf öğretmeni adaylarının özel alan yeterlik algılarının çeşitli değişkenler açısından analizi. Uluslararası Türkçe Edebiyat Kültür Eğitim Dergisi, 2(2), 285-301.

Kaya, V. H., Polat, D. ve Karamüftüoğlu, İ. O. (2014). Öğretmen adaylarının öğretmen yetiştirme ile ilgili görüşlerinin belirlenmesi. The Journal of Academic Social Science Studies, 30, 569-584. 
Kennedy, M. M., Ahn, S., \& Choi, J. (2008). The value added by teacher education. In Cochran-Smith M., Feiman Nemser S., \& McIntyre D. J. (Eds). Handbook of research on teacher education: enduring questions in changing contexts (pp. 1247- 1271). New York: Routledge/Taylor Francis \& The Association of Teacher Educators.

Kılınç, A. ve Gödek Altuk, Y. (2010). "Sınıf öğretmeni adaylarının okul deneyimi derslerine yönelik tutumları", Mehmet Akif Ersoy Üniversitesi Eğitim Fakültesi Dergisi, 10(19), 41-70.

Koyuncu, F. (2016). Eğitim izleme raporu 2015-16: "Öğretmenler” arka plan raporu. Eğitim Reformu Girişimi. http://www.egitimreformugirisimi.org/wp-content/uploads/2017/03/EIR2015-

16_ArkaPlanRaporu_Ogretmenler_FK.pdf adlı siteden 29.01.2019 tarihinde alınmıştır.

Menon, M. (2007). An anthology of "best practices" in teacher education. In T. K. S. Lakshmi, K. Rama, Johan Hendrikz). National Assessment and Accreditation Council (NAAC).

Miles, M. \& Huberman, A. M. (1994). Qualitative data analysis: An expanded sourcebook, CA: SAGE Publications.

Ok, A. ve Önkol, P. (2007). Öğretmen yetiştirme programlarındaki öğretmen adaylarının profili. Eğitim ve Bilim, $32(143), 13-25$.

Okçabol, R. (2004). Öğrenci, öğretmen, öğretmen adayı ve öğretim elemanı gözüyle öğretmen yetiştirme!, XIII. Ulusal Eğitim Bilimleri Kurultayı, 6-9 Temmuz 2004 İnönü Üniversitesi, Eğitim Fakültesi, Malatya.

Okçabol, R., Akpınar, Y., Caner, A., Erktin, E., Gök, F. ve Ünlühisarcıklı, Ö. (2003). ögretmen yetiştirme araştırması (survey of teacher training). Ankara: Eğitim Sen Yayınları.

Oktay, A. (1991). Öğretmenlik mesleği ve öğretmenin nitelikleri. M.Ü. Atatürk Ĕ̆itim Fakültesi Ĕ̆itim Bilimleri Dergisi, 3, 187-193.

Özay Köse, E. (2014). “Okul deneyimi ve öğretmenlik uygulaması derslerine yönelik öğrenci ve öğretmen-öğretim elemanı tutumları (Erzurum örneği)”, Dicle Üniversitesi Ziya Gökalp Eğitim Fakültesi Dergisi, 22(2014), 117.

Özgüngör, S. ve Duru, E. (2015). Course and instructor characteristics distinguishing highest and lowest student ratings of instructors. Eurasian Journal of Educational Research, 61, 118-136.

Özoğlu, M. (2010). Türkiye'de öğretmen yetiştirme sisteminin sorunları. SETA-Siyaset, Ekonomi ve Toplum Araştırmaları Vakfi, 17, 1-37.

Özsoy, G., Özsoy, S., Özkara, Y. ve Memiş, A.D. (2010). Öğretmen adaylarının öğretmenlik mesleğini tercih etmelerinde etkili olan faktörler. İlkögretim Online, 9(3), 910-921.

Öztürk, M. ve Yıldırım, A. (2014). Göreve Yeni Başlamış Öğretmenlerin Türkiye’deki Hizmet-öncesi Öğretmen Yetiştirme Hakkındaki Görüşleri. Journal of Teacher Education and Educators, 3 (2), 149-166.

Saracaloğlu, A. S., Yılmaz, S., Çöğmen, S. ve Şahin, Ü. (2011). "Sınıf öğretmeni adaylarının okul deneyimi dersine ilişkin görüşleri”, Mehmet Akif Ersoy Üniversitesi Eğitim Fakültesi Dergisi, 11(22), 15-32.

Sarıtaş, M. (2007). Determining in what level of the course 'School Experience 1' is benefical for preservice teachers. Uludă Üniversitesi Eğitim Fakültesi Dergisi, 20(1), 121-143.

Şahin, Ç., ve Kartal, O. Y. (2013). Sınıf öğretmeni adaylarının sınıf öğretmeni yetiştirme programı hakkındaki görüşleri. Uşak Üniversitesi Sosyal Bilimler Dergisi, 12, 164-190.

Taş, İ. D., Kunduroğlu-Akar, T. ve Kıroğlu, E. (2017). Sınıf öğretmenliği lisans programının öğretim üyeleri ve öğretmen adaylarının görüşleri doğrultusunda değerlendirilmesi. Yüksekögretim ve Bilim Dergisi/Journal of Higher Education and Science, 7(3), 578-592.

TEDMEM (2014). Öğretmen gözüyle ögretmenlik mesleği. Rapor Dizisi: 3 Ankara, 1-66.

Tom, A.R. (1997). Redesigning teacher education. Albany, NY: State University of New York.

Topkaya, Y., Tokcan, H. ve Kara, C. (2012). Öğretmenlik uygulaması dersi hakkında sosyal bilgiler öğretmen adaylarının görüşleri, The Journal of Academic Social Science Studies, 5/7, 663- 678.

Tunca, N., Alkin-Sahin, S., Oguz, A. \& Bahar-Guner, H. O. (2015). Qualities of ideal teacher educators. Turkish Online Journal of Qualitative Inquiry, 6(2),123-148.

Turhan, M., Demirli, C. ve Nazik, G. (2012). Sınıf öğretmenlerinin mesleğe adanmışlık düzeyine etki eden faktörler: Elazığ örneği. İstanbul Ticaret Üniversitesi Sosyal Bilimler Dergisi, 11(21), 179-192.

Ubuz, B. ve Sarı, S. (2008). Sınıf öğretmeni adaylarının öğretmenlik mesleğini seçme nedenleri. Pamukkale Üniversitesi Eğitim Fakültesi Dergisi, 24, 113-119.

UNICEF (2000). Defining quality. A paper presented at the International Working Group on Education meeting, Florence Italy, June 2000. (Principal researcher: Jeanette Colby).

Wei, R. C., Andree, A., \& Darling-Hammond, L. (2009). How nations invest in teachers. Educational Leadership, 66 (5), 28-33.

Yavuzer, Y., Dikici, A., Çalışkan, M., \& Aytekin, H., (2006). Sınıf öğretmenliği mezunlarının öğretmen yetiştirme programlarından yararlanma düzeylerine ilişkin görüşleri. Çukurova Üniversitesi Eğitim Fakültesi Dergisi, 3(32), 35-41.

Yıldırım, A. ve Şimşek, H. (2005). Sosyal bilimlerde nitel araştırma yöntemleri. Ankara: Seçkin Yayınları.

Yıldırım, A. ve Şimşek, H. (2013). Sosyal bilimlerde nitel araştırma yöntemleri (9.Baskı). Ankara: Seçkin Yayınları.

Yılmaz, A. ve diğerleri. (2017). Türkiye'de Öğretmen Eğitimi ve İstihdamı: Mevcut Durum ve Öneriler. http://www.egitim.hacettepe.edu.tr/belge/OgretmenEgitimi-istihdam_Raporu.pdf adlı siteden 29.01.2019 tarihinde alınmıştır. 